Collaborative Learning in the Colombian Educational System: A Literature Review

\title{
Job Gabriel Yepes Espitia
}

Research Report submitted in partial fulfillment of the requirements for the degree of Master in English Language Teaching for Self-Directed Learning\| (Online Program)

Directed by: María Catalina Caro Torres Department of Foreign Languages and Culture

Universidad de La Sabana

Chia, Colombia

2019 


\section{Declaration}

I hereby declare that my research report entitled: "Collaborative Learning in the Colombian Educational System: A Literature Review"

- $\quad$ Is the result of my own work or research circle members 'work

- Declares which is the outcome of work done in collaboration as declared and specified in the text;

- Is neither substantially the same as nor contains substantial portions of any similar work submitted or that is being concurrently submitted for any degree or diploma or other qualification at the Universidad de La Sabana or any other university or similar institution except as declared and specified in the text;

- $\quad$ Complies with the word limits and other requirements stipulated by the Research Subcommittee of the Department of Languages and Cultures;

- Has been submitted by or on the required submission date.

Date: February, 2019

Full name: Job Gabriel Yepes Espitia

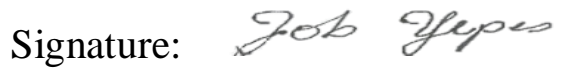




\section{Acknowledgments}

I wish to thank the external advisor professor Blanca Lucia Cely Betancourt for her comments on the first submitted version of this thesis. This final version has benefitted a great deal because of her comments. Further thanks must go to professor Martha Jeanette Moreno Torres for consulting with me about proper citations.

I would also like to give full credit to Debra Vaughn, as she not only kept me sane during this process but was invaluable with her knowledge of English grammar. I am grateful also to professors Claudia Acero and Maria Catalina Caro who patiently encouraged me and were gracious with their corrections during the writing process.

Last, but not least, I wish to dedicate this thesis to my parents, my mother, Blanca de Yepes and my father, Manuel Yepes who passed away while I was undertaking this study. I owe my entire life to them. 


\begin{abstract}
The Ministry of Education (MEN) in Colombia has been interested in improving the communicative competence in English, in this way English has been selected as the official foreign languages to be taught because it is the third spoken language in the world and more than 200 million people use it as their second language. The aim to the Colombian government is to implement a bilingualism program. Since 2004 a national educational policy as well as different bilingual initiatives have been implemented, this is something that is still happening in order to have a bilingual country by 2025 .
\end{abstract}

English teachers have been interested in including new technologies and approaches that facilitate the teaching-learning processes at all the educational levels, as it is show in the systematic review that was done to develop this research. It provided a general overview of literature on this specific topic through these stages: Scoping, Planning, Identification (searching), Screening and Eligibility. This study shows that during the last decades the implementation of collaborative learning has had successful results. It was also found that sometimes teachers have misconceptions and lack of training in the use of this approach. This results in the unsuccessful implementation of collaborative learning in the classroom.

Key words: Collaborative learning, Second language, Bilingualism in Colombia, educational system, approach

\title{
Resumen
}

El gobierno colombiano ha estado interesado en el bilingüismo. Desde 2004, se ha implementado una política educativa nacional y 26 se han implementado diferentes iniciativas 


\section{COLLABORATIVE LEARNING IN THE COLOMBIAN EDUCATIONAL SYSTEM iv}

para tener un país bilingüe para el año 2025. Colombia seleccionó el inglés como el idioma oficial extranjero a enseñar porque es el tercer idioma más hablado en el mundo como lengua materna y el segundo más hablado, después del chino mandarín, significa que más de 200 millones de personas es su segundo idioma.

Es por eso que los profesores de inglés han estado interesados en incluir nuevas tecnologías y enfoques que faciliten los procesos de enseñanza-aprendizaje en todos los niveles educativos. Para esta investigación se realizó una revisión sistemática que proporcionó una visión general de la literatura sobre este tema específico a través de estas etapas: alcance planificación, identificación (búsqueda), Revisión y Elegibilidad. Este estudio muestra que durante las últimas décadas la implementación del aprendizaje colaborativo ha arrojado resultados exitosos y los beneficios de la implementación de este enfoque, sin embargo, también se encontró que a veces los maestros tienen conceptos erróneos y falta de capacitación en el uso de este enfoque que hace que la implementación del aprendizaje colaborativo no se implemente de manera exitosa en el aula.

Palabras clave Aprendizaje colaborativo, Segundo idioma, Bilingüismo en Colombia, sistema educativo, enfoque. 


\section{Table of Contents}

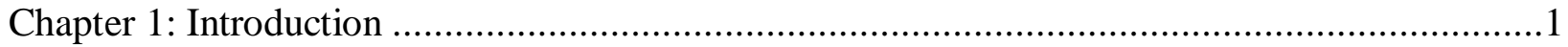

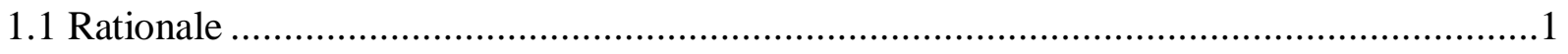

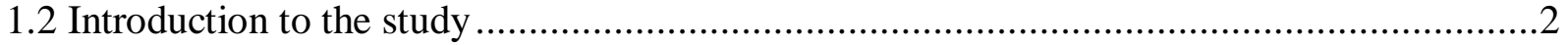

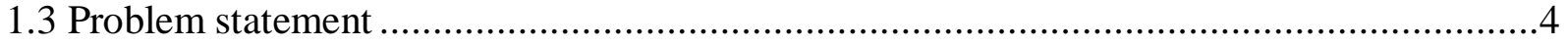

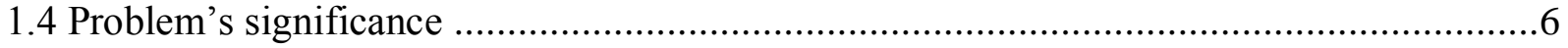

1.5 Strategy selected to address problem ………….........................................................

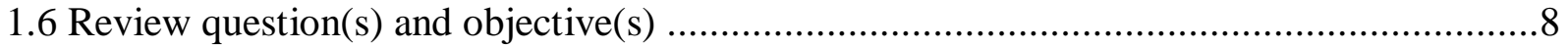

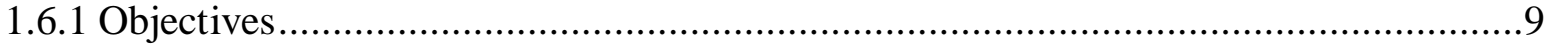

Chapter 2: Relevant theoretical bases for the review and other reviews ...................................10

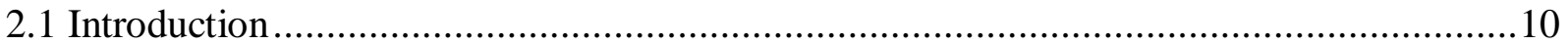

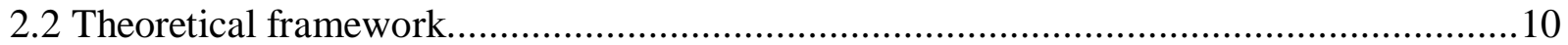

2.2.1. Defining collaborative learning ......................................................................... 10

2.2.2 Differences and implications in this approach .......................................................13

2.2.3 Collaborative learning and information and communications technology, or

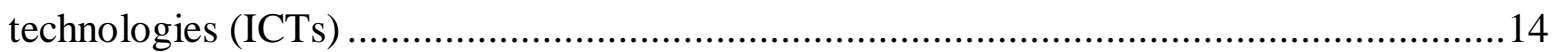

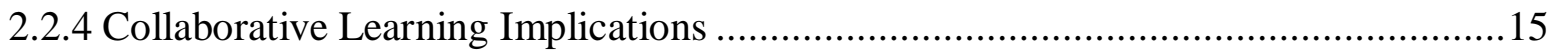

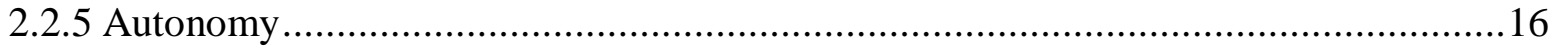

2.2.6 Implementing Cooperative Learning ....................................................................20

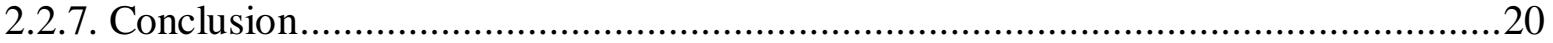

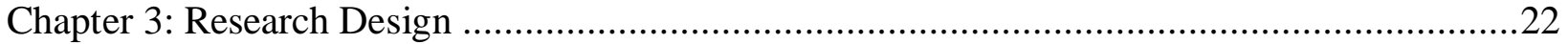

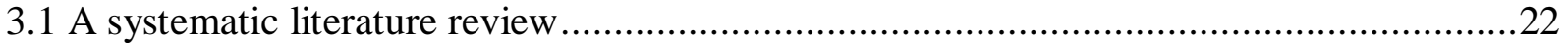

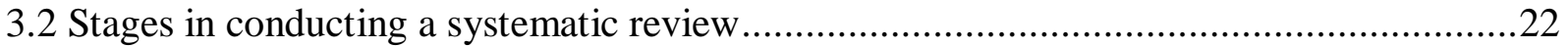

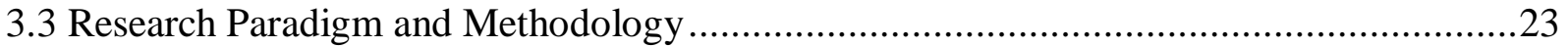

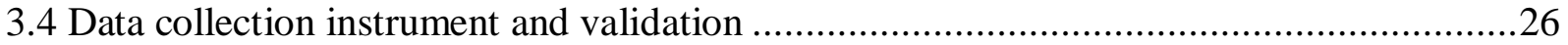

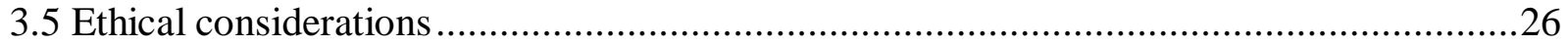

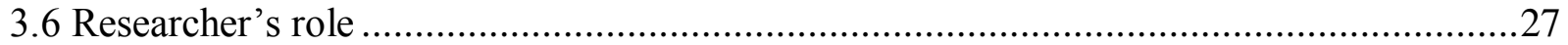

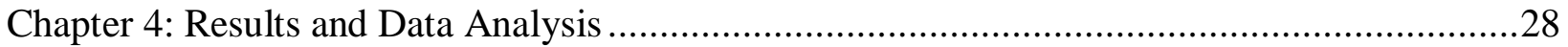

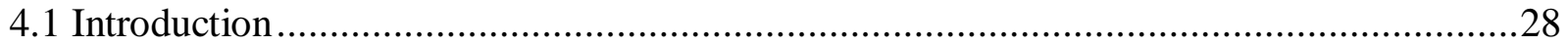

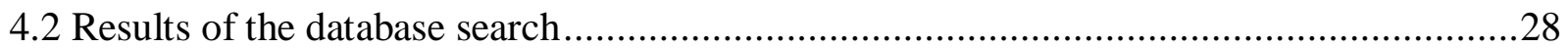




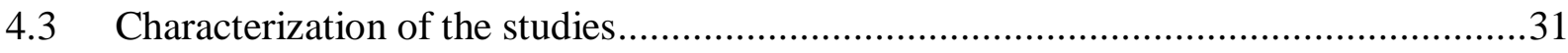

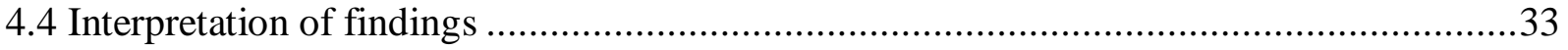

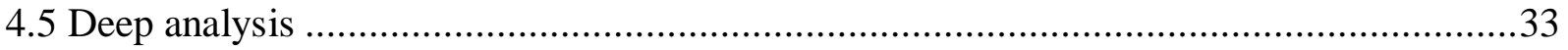

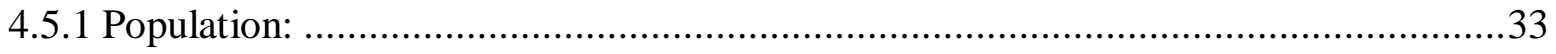

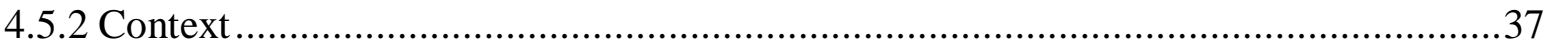

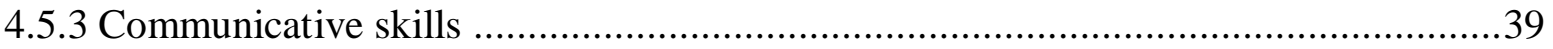

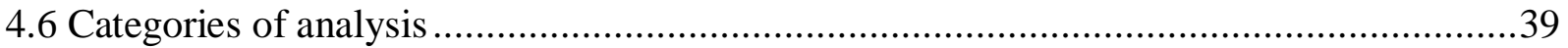

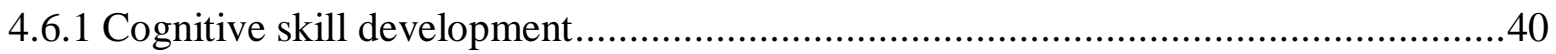

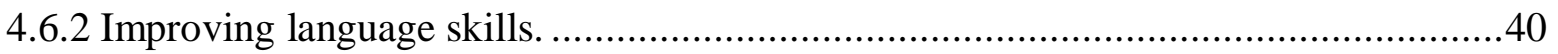

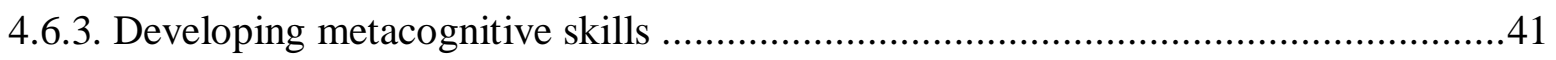

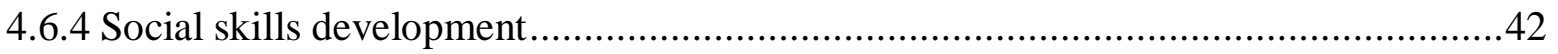

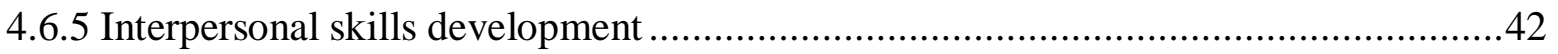

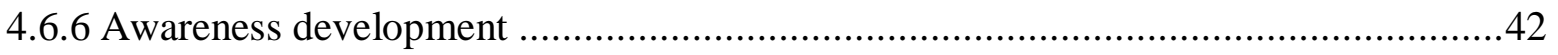

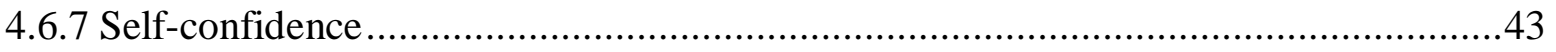

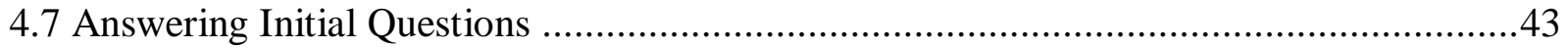

Chapter 5: Conclusions and Pedagogical Implications ............................................................49

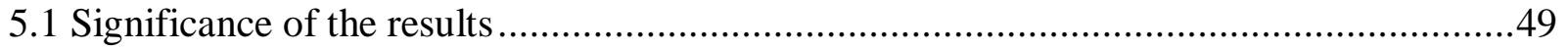

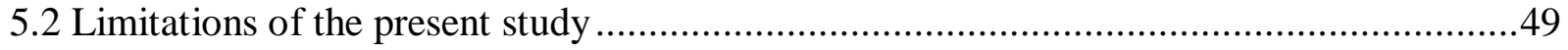

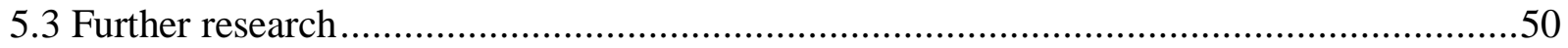

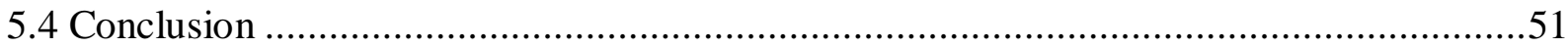

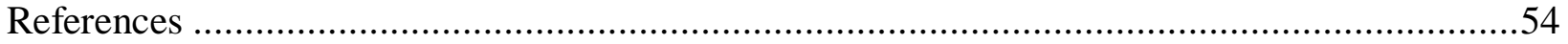

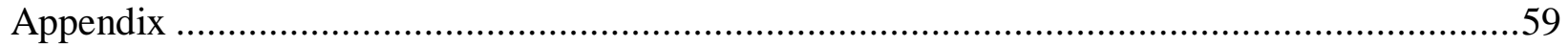

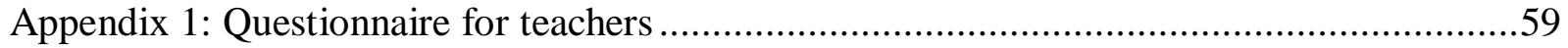

Appendix 2: List of Articles included on the preliminary stage..............................................60

Appendix 3: Articles related to collaborative learning and autonomy ....................................61

Appendix 4: Articles found about Collaborative Learning ...................................................62

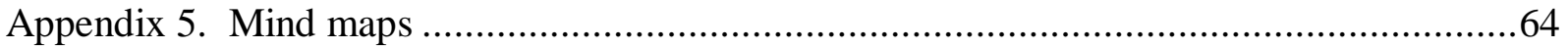

\section{Table of figures}


Figure 1. Evolution of Cooperative Learning ........................................................... 15

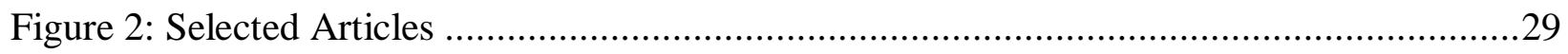

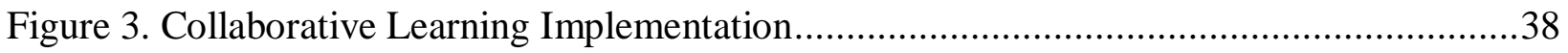

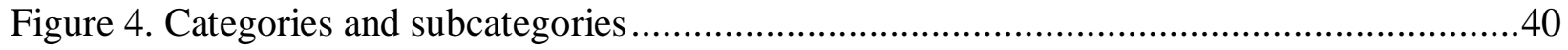

\section{Table of tables}

Table 1. Collaborative Learning Definition ...................................................................11

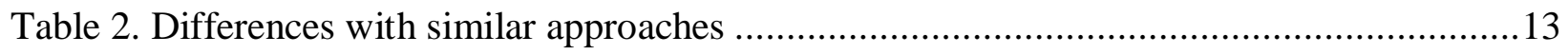

Table 3. Different definitions about autonomy learning ................................................... 17

Table 4. Stages to Conduct a Systematic Review according to Baumeister\& Leary, 1997; and

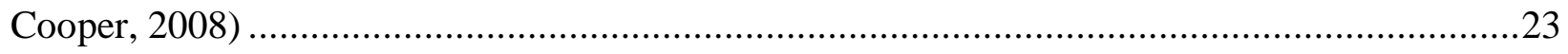

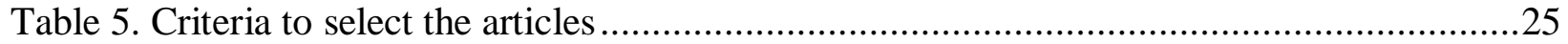

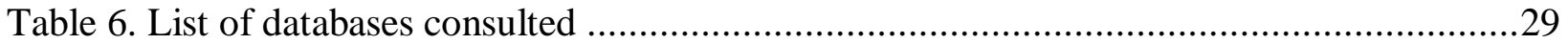

Table 7. Differences between Collaborative and Cooperative Learning ................................30

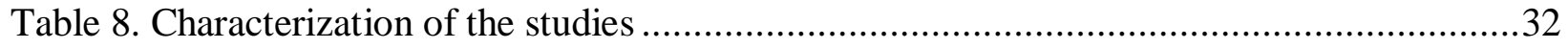

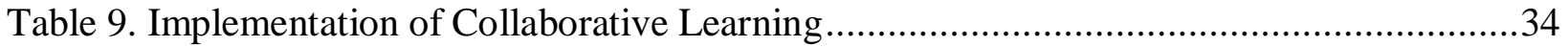

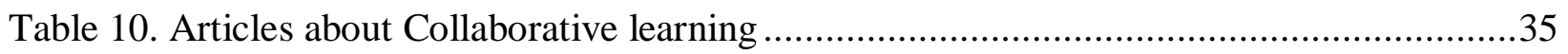

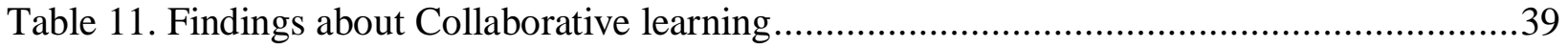

Table 12. Definitions about Collaborative Learning …...............................................44

\section{LIST OF ABBREVIATIONS}

CL Collaborative Learning

COL Cooperative Learning

PPL Peer to peer learning

FL Foreign Language

CSCL Computer-supported Collaborative Learning

CNL Collaborative Networked Learning 


\section{Chapter 1: Introduction}

\subsection{Rationale}

The educational system has changed and so have teachers' roles. Nowadays, second language teachers are guides and facilitators of the students' learning process rather than judges or evaluators. Therefore, one of the most important role teachers have is to motivate students, making them aware of the capabilities and responsibilities they have in learning process. It is well known that collaborative learning (CL) increases students' motivation by giving them more control over their learning experiences states by Quinn (2006).

On the other hand, students must take control over their learning process and be attentive to new challenges that modern society demands. Holec (1981) highlights the importance of reflecting about the responsibility students have in their learning process and the importance of their autonomy to achieve freedom as individuals. Students can work competitively to reach their own goals.

One of the most important issues is a teacher must help students to develop autonomy by teaching strategies to learn a foreign language rather than just transmitting grammar rules or vocabulary.

Learning a foreign language is a process that implies motivation, effort and daily work. However, it needs more than what a teacher can do during class. Students must do more activities at home to get better results.

Studies, such as the one done in Singapore in, 2016 by Christopher Pang, demonstrated collaborative learning promotes social skills because students could interact with each other, giving, and listening to opinions and ideas which in turn improves relationships. Collaborative 
learning encourages students to have higher achievements instead of competitive or individualistic learning. It offers learners opportunities that enable them to increase their selfesteem and to become more intrinsically motivated (Kagan (1994). Also, collaborative learning promotes cognitive and meta - cognitive skills due to the fact interactions with other dexterities build new knowledge. It has also been an effective approach in enhancing communicative skills in second languages, such as reading and writing, (Cole, 2012; Elola \& Oskoz, 2010; Wong 2009; Mason, 2006; Chen, 2004; Atkinson, 2003; Mariam, 2004; Chandrika, 2001). They also state that implementing collaborative learning makes students improve their communicative skills.

Atkinson (2003) for example, states collaborative learning improves writing. Writing instruction is not only getting students to put pen to paper, but it also needs personal interaction to develop students' responses towards texts. In the same way, Kim and Kim (2005) suggest applying this approach when teaching because students would be expected to make, organize, and share ideas. Therefore, they would be able to manage the other components of writing such as vocabulary, spelling, purpose, target audience, and mechanics.

\subsection{Introduction to the study}

Collaborative learning plays an important role in the English language learning process. Nowadays learners' autonomy is an important factor as each student has qualities, skills and abilities enabling them to take an active role in their own second language learning process

Recent studies in Colombia have demonstrated that collaborative learning has been used as an innovative approach and it has given excellent results in language learning (Lopera, 2014). Gaillet (1994) stated that the implementation of collaborative learning has several benefits 
associated with the success of the second language learning processes. Other study done in Colombia shows that CL and writing skills can be worked together to improve several academic and personal skills (Caicedo, 2016).

Collaborative learning (CL) has many advantages according to the findings in schools, universities, and groups of study in Colombian institutions where it was applied. This is an approach that facilitates work in the classroom. It fosters students' motivation as students are involved in their own learning process. Learners work at their own pace on a topic of interest, interacting collaboratively with learners who are familiar with the theme or who are keen to know more about it. Brown and Lara (2011) cited by Johnsons (2009, p. 489) state that; when students have the opportunity to work together, they can promote success to others; they can also work competitively to reach their own goals, or they can work individually to achieve personal goals distinct of others, autonomy is important as to achieve freedom as individuals, Holec (1981).

The main objective of this paper is to present the findings of CL reported by various foreign language researchers in Colombia and how CL has been implemented in the acquisition of English as a foreign language in different contexts and different levels of proficiency. The conclusions found in these research projects can help foreign language teachers to understand and implement this approach in their own context since this literature review works with papers from different educational areas in Colombia. This paper focuses on collaborative learning in the second language teaching area. It shows mainly the results of some researches in Colombia that have proven the success of this approach.

This thesis is divided into five chapters; chapter 1 presents the need for conducting a literature review on the topic of collaborative learning, including the problem statement and 
problem significance. The main research question and objectives of the research project will also be stated. Chapter 2 includes the literature review focusing specifically on how the collaborative learning approach has been implemented in Colombia. Chapter 3 explains the importance of a systematic review and describes the steps followed to collect the data for further analysis. Chapter 4 presents a characterization of the studies obtained and provides an analysis of the findings. The analysis is divided into two phases: the first phase identifies key aspects of the studies chosen to present a general perspective of the topic; and the second part corresponds to an in-depth analysis of the results of the literature review on the topic. Finally, chapter 5 presents the main conclusion and the pedagogical implications of this research project.

\subsection{Problem statement}

Collaborative learning is an approach based on the view that knowledge is a social construct. It means that individuals construct their own meaning assisted by others in a collaborative way. This approach has been demonstrated to benefit student's learning process because of reasons such as: it develops a higher-level of thinking; it promotes oral communication and interaction as students can acquire leadership skills; to increases students' responsibility and their ability to participate expressing their own ideas and points of view, as Gillies (2006) states. This approach prepares students for daily life situations as they can learn different methods to solve problems, how to listen to others, and express their opinions. This helps students to be ready to face the demands of situations in the future, i.e. job interviews, teamwork.

Although collaborative learning is not a new approach, most teachers are unaware of this approach and its benefits. Johnson and Johnson (1993) state that there is always a danger of 
incorrect implementation of collaboration because of inadequate training, which results in teachers' frustration. Most teachers think collaborative learning only refers to making students work in groups to carry out a task. To confirm Johnson and Johnson's hypothesis, 10 out of 15 school teachers were asked about the use of this approach in their English classes. I used simple questions in informal interviews to indagate the use of CL approach in the English class. The result was not positive because more traditional teachers rarely made activities in groups during their classes as they thought collaborative learning had disadvantages. Some teachers were concerned students might assume a passive role in the group and not contribute to the development of the corresponding activity.

Classes in Colombia are large and heterogeneous, sometimes 40 students or more; Teachers prefer to ask students to work individually to have better class control. In addition, some of them think collaborative learning contributes to bad behavior and class management becomes harder. Most teachers may not know the advantages of collaborative learning and the impact it plays on developing students' interpersonal skills. It seems most of the teachers prefer passive classes and they feel afraid of promoting activities in which students assume an active role because of discipline issues. As Schug, Tarver and Western (2001) state, some teachers believe instructions centered provided by teachers were associated with improving student learning.

Collaborative learning strategies can be implemented as peer-to-peer instruction or in larger groups. Peer learning, or peer instruction, is a type of collaborative learning that involves students working in pairs or small groups to discuss concepts or find solutions to problems. It also promotes social skills; "collaborative learning has as its main feature a structure that allows 
for student talk: students are supposed to talk with each other and it is in this talking that much of the learning occurs." (Golub, 1988).

The success of this approach depends on the design and implementation of the group activities. There is a need to comprehensively know this approach to identify the advantages it brings. Different reports of some related research studies that have been carried out in Colombia have shown it is possible to implement this approach despite the number of students per group, their ages or language level.

\subsection{Problem's significance}

Although it has been implemented in different contexts, there is a lack of awareness about collaborative learning. In the classroom, as in the society, individuals need to think and work together on issues of critical concerns (Austin, 2000). It has become a twenty-first-century trend; however, it is challenging for teachers working with groups of students who are shy and passive recipients of knowledge rather than active participants in class. It could be due to the teacher's tendency to talk and transmit knowledge while students are required to simply listen, repeat and answer, reiterating information provided by the teacher (Galton, Hargreves, Comber, Wall \& Pell 1999).

In some cases, when students are placed in groups, there is little instruction for students to reflect on their roles in the group, the purpose of the activity they must undertake, and there is no discussion on how they can resolve difficulties (Baines, 2003). That is why it is important to provide teachers with ongoing professional development and training in the application of CL in the classroom (Webb, 2009). 
It is necessary for teachers to know the approach, the research carried out and the results of implementing CL to ensure tasks are complex and challenging enough (Cohen, 1994). Also, it is needed to provide students with opportunities to develop social skills required to manage conflict, to monitor and review the group's progress (Johnson \& Johnson, 2003). In other words, before implementing CL teachers should reflect on the importance of implementing this approach to contribute to the development of students' social skills, which is a practice usually neglected in the classroom.

\subsection{Strategy selected to address problem}

For this research, a systematic literature review ${ }^{1}$ of papers published from 2000 to 2016 in Colombia was done, in order to identify evidence based on rigorous research papers on the implementation of CL.

This section presents the strategies and criteria adopted to carry out this review, the organization of information, and the biographic research. To write this paper, first, the type of revision to be implemented was decided. A theoretical review was done to examine the corpus of theory that has been stated in regard to CL, the research studies in this field have been carried out in Colombia, as well as the concept, theory and phenomena. This theoretical literature review aims to establish and systematize current theories in Colombia.

This review will be done through an exhaustive bibliographical search of information sources. According to Dankhe (1989) there are three types of sources: a) primary or original

\footnotetext{
${ }^{1}$ A strategy to identify and synthesize studies that directly relate to the systematic review question.
} 
sources: They correspond to first-hand data such as books, scientific journals, conferences, etc. b) Secondary sources: They help the researcher find the required references. These sources are compilations, summaries and reference lists published in a particular area of knowledge such as catalogs, systematic reviews, summaries, and databases. c) Tertiary sources used when the theme is completely new, and the researcher does not know anything about it. For this review, primary and secondary sources have been used. This topic was not new for the researcher and the purpose was to compile information and research studies on this topic in Colombia.

To sum up, the topic was selected considering the researcher's own interest and the latest trends in education. Then an exhaustive search of the information was carried out, including both the theoretical framework and related research studies done in this field. All the information was compiled and analyzed in order to write the final report.

\subsection{Review question(s) and objective(s)}

To carry out this research project, a review of this approach, its definitions and implications in the classrooms were first done. Some questions were considered:

1. What is the general definition of CL approach according to the literature review included in the selected articles?

The second step was reviewing research projects about the CL implementation in Colombia while considering the population, study dates, education sector, aims and findings.

1. What are the results of implementing CL and student's outcomes in research studies done in Colombia?

2. What communicative skills has been developed using CL approach in Colombia? 
3. What are the advantages and disadvantages of implementing this approach in the foreign language learning and teaching in Colombia?

\subsubsection{Objectives}

\section{General}

Elaborate a review of literature about the implementation of Collaborative Learning Approach in foreign language teaching contexts in Colombia during the last decade in order to find a general definition of CL approach and its implications according to the literature review included in the selected articles.

\section{Specific}

$>$ Revise research studies done about the Collaborative Learning Approach in Colombia during the last decade to know experiences and student's outcomes.

$>$ Identify the different foreign language learning contexts in Colombia in which the Collaborative Learning Approach has been applied and studied.

$>$ To identify the advantages or disadvantages of implementing this approach in the foreign language learning in Colombia? 


\section{Chapter 2: Relevant theoretical bases for the review and other reviews}

\subsection{Introduction}

This section presents a general outline of this paper. In addition, it points out the pedagogical implications of using this approach. First it is presented the theoretical review which give a specific idea about collaborative learning as an umbrella term that involves different strategies. Then it is given a complete comparison among definitions from different authors about collaborative learning, in the same way it is also given the differences among CL and other similar approaches that tend to be confusing. Finally, it is presented the implications of collaborative learning.

\subsection{Theoretical framework}

\subsubsection{Defining collaborative learning}

Collaborative learning is an umbrella term that covers intellectual effort by teachers and students or students together according to Mac Gregor (1990). In collaborative learning, students work in small groups; they reciprocally try to understand and find a solution in order to present a product at the end. This approach is mostly student centered rather than teacher-centered. It implies material preparation and a lesson plan that fosters a good environment and makes all the members of the group work together collaboratively. According to Bruffee (1996), collaborative learning started in the middle of the eighteenth century in Britain as a consequence of the predominant authoritarian teaching style. It was noticed that students had problems with traditional methods, it was the moment when researchers looked into the problem and suggested 
other alternatives to teach their classes. To clarify the meaning of CL, different sources of literature were explored. Results are shown in table 1.

Table 1. Collaborative Learning Definition

\begin{tabular}{|c|c|c|}
\hline Definition & Author & Year \\
\hline $\begin{array}{l}\text { Learning environment that maximizes the learner's ability to interact } \\
\text { with each other through discussion, collaboration, and } \\
\text { feedback. Culture is the primary determining factor for knowledge } \\
\text { because we learn by interacting with others and following rules. }\end{array}$ & Vygotsky & 1962 \\
\hline $\begin{array}{l}\text { A structure that allows for student talk, in which students are } \\
\text { supposed to talk with each other, and it is in this talking that much } \\
\text { of the learning occurs. }\end{array}$ & Golub & 1988 \\
\hline $\begin{array}{l}\text { Collaborative teaching and learning is a teaching approach that } \\
\text { involves groups of students working to } \\
\text { solve a problem, complete a task or create a product }\end{array}$ & MacGregor & 1990 \\
\hline $\begin{array}{l}\text { knowledge is constructed, } \\
\text { discovered, and transformed by students } \\
\text { A paradigm of teaching knowledge is constructed, discovered, and } \\
\text { transformed by students. }\end{array}$ & $\begin{array}{l}\text { Johnson, Johnson \& } \\
\text { Smith }\end{array}$ & 1991 \\
\hline $\begin{array}{l}\text { An umbrella term for a variety of educational approaches involving } \\
\text { joint intellectual effort by students, or students and teachers } \\
\text { together for understanding, solutions, or meanings, or creating a } \\
\text { product. CL activities vary widely, but most center on student's } \\
\text { exploration or application of the course material, not simply the } \\
\text { teacher's presentation or explication of it. }\end{array}$ & $\begin{array}{l}\text { Smith, B.L. \& } \\
\text { MacGregor }\end{array}$ & 1992 \\
\hline $\begin{array}{l}\text { Learning is a naturally social act in which participants talk among } \\
\text { themselves. It is through the talk that learning occurs. }\end{array}$ & Gerlach, J.M. & 1994 \\
\hline $\begin{array}{l}\text { The grouping and pairing of students for the purpose of achieving } \\
\text { an academic goal. }\end{array}$ & Gokhale, A & 1995 \\
\hline $\begin{array}{l}\text { A situation in which two or more people learn or attempt to learn } \\
\text { something together as a pair or small group of 3-5 subjects or a } \\
\text { class } 20-30 \text { subjects). Performing learning activities such as } \\
\text { problem solving. It could be face-to-face or computer-mediated. }\end{array}$ & Dillenbourg, $\mathrm{P}$. & 1999 \\
\hline
\end{tabular}


Reviewing what some experts have stated about Collaborative Learning, most of them agree in defining it as an approach that involves intellectual capacities subjects develop in order to join efforts together to find a solution to a task. It has been considered an umbrella term because there are varieties of this methodology. For instance, Dillenbourg (1999) states that CL could be developed either face to face or computer mediated, in small groups or groups of 20 or 30 people. Group members' abilities and contributions help to prepare and solve a task. This is an important aspect experts mention, as well as the importance of the responsibility that each one has as a member of the group.

Analyzing the advantages, CL has proven to be a successful approach with different ages of foreign language students, especially with young learners, in this way, the teacher can teach them social skills to improve their relationship rather than simply transmitting concepts and ideas. Nowadays, people need to develop social skills in order to accept and respect ideas from others. They should value contributions as well as share their own ideas in order to establish thoughts, solve a problem, complete a task or obtain a product. It is also important to mention that individuals should know that knowledge is constructed in the community (Vygotsky, 1978).

$\mathrm{CL}$ is an approach that can be implemented with students of all ages, learning styles, and backgrounds because all of them can make contributions depending on their own previous experiences and knowledge. Gokhale (1995) declares CL is a proper approach because students improve their critical thinking and they are able to accomplish higher levels of learning as they work in groups rather than individually. Also, they are able to retain more information when it is received from their peers. CL also promotes interaction, communication and active participation instead of the passive way of receiving information from the teacher. 


\subsubsection{Differences and implications in this approach}

Different ways to carry out and implement this approach can be confusing; that is why it is important to clarify the differences among collaborative learning, peer-to-peer learning, and cooperative learning.

Table 2. Differences with similar approaches

\begin{tabular}{|c|c|c|}
\hline Approach & Definition & Author \\
\hline Peer to peer learning & $\begin{array}{l}\text { It is where one student leads another } \\
\text { through a concept, in which the first } \\
\text { student is an 'expert' and the second is a } \\
\text { novice. The peers do not necessarily need } \\
\text { to be from the same class or age group. }\end{array}$ & $\begin{array}{l}\text { Johnson, D.W., Johnson, } \\
\text { R.T., \& Holubec, E.J. (1993) }\end{array}$ \\
\hline Collaborative learning & $\begin{array}{l}\text { Collaborative learning is } \\
\text { learning with each other. Collaborative } \\
\text { Learning increases student's awareness of } \\
\text { other concepts. }\end{array}$ & Vygotsky \\
\hline Cooperative learning & $\begin{array}{l}\text { Cooperative learning implies each } \\
\text { individual takes responsibility for a } \\
\text { specific part of the work and then } \\
\text { coordinates with the others to join all the } \\
\text { parts. } \\
\text { In cooperative learning model, the } \\
\text { following } 5 \text { principles and elements should } \\
\text { be included, according to Johnson (1993) } \\
\text { 1. Positive interdependence } \\
\text { 2. Individual accountability } \\
\text { 3. Face-to-face promotive } \\
\text { interaction. } \\
\text { 4. Appropriate use of social, } \\
\text { interpersonal, collaborative and } \\
\text { small-group skills. } \\
\text { 5. Group processing }\end{array}$ & $\begin{array}{l}\text { Dillenbourgh, P., Baker, M., } \\
\text { Blaye, A. \& O’Malley, C. } \\
\text { (1995). }\end{array}$ \\
\hline
\end{tabular}

Collaborative and cooperative learning could be confused; but they are actually not alike. According to the experts and definitions given in the table above, CL implies the mutual 
engagement of participants and combines all efforts to figure out a task or a work. Cooperative learning implies individual accountability to contribute to the group's success; each student takes responsibility of a specific task that is part of a project or a product. On the other hand, some authors believe cooperative learning is used for primary education, to understand the basis of knowledge, while CL is used for college and university students because it is used to teach nonfoundations of learning. However, there are similarities as both of them are group learning approaches, implying students take an active role in the class; and both of them suggest social responsibility and social skill development.

\subsubsection{Collaborative learning and information and communications technology, or technologies (ICTs)}

New technology has become an important aspect in education and it has had an important impact on students learning process. The use of the internet, for example, allows for communication and interaction between individuals and groups. Nowadays, virtual environments are common. Recent research studies have been conducted to investigate how new technology fosters collaborative learning. These studies show students are able to learn even when they were not present at their university campus (Stacey, 1999).

According to Findley (1987), the use of ICTs has increased in CL and it is called Collaborative Networked Learning (CNL). This refers to the learning process that occurs through online interaction. In this process, each learner actively interacts in a group and exchanges knowledge with one another within a contextual framework. There is a new paradigm in education called Computer-supported collaborative learning (CSCL) which refers to the use of 
technology in learning environments to support group interactions in a collaborative learning context. CSCL provides new knowledge using technology to complete a task or product.

Nowadays, CL has evolved, and teachers have started to take advantage of ICTs to promote communication and interaction in collaborative tasks. Even now the use of 3D models facilitates and motivate students' participation in group activities. This way, CL in virtual environments provides an excellent opportunity to promote the foreign language learning process.

Figure 1. Evolution of Cooperative Learning
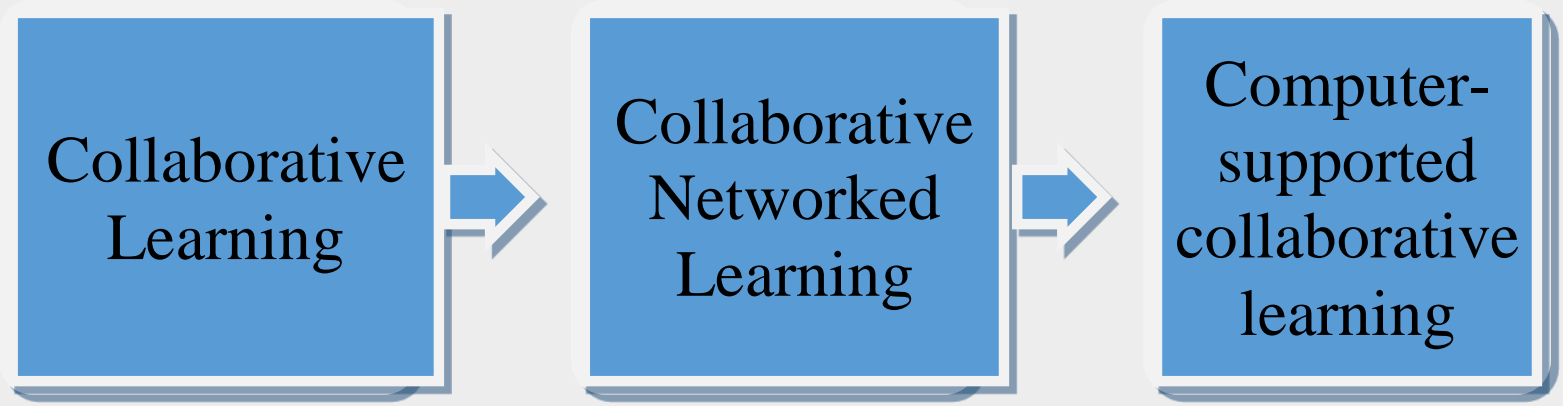

Font: Researcher design

\subsubsection{Collaborative Learning Implications}

Collaborative learning has some pedagogical implications that experts consider are vital in order to successfully observe its outcomes. For instance, Slavin (1997) suggests four key theoretical perspectives to explain the positive effects of collaborative learning: motivation, social cohesion, developmental, and cognitive elaboration perspectives.

$>$ Motivational perspectives. Students in CL should feel interested and motivated as group members. All must feel they are an active member of the group and know their 
COLLABORATIVE LEARNING IN THE COLOMBIAN EDUCATIONAL SYSTEM 16

responsibilities to make the group successful. All members of the group must help and encourage their mates to succeed.

$>$ Social Cohesion Perspectives. This refers to the cohesiveness of the group. This approach emphasizes team-building activities in preparation for collaborative learning instead of using external motivations and individual responsibilities. Students help their group mates learn because they care about the group's interest.

$>$ Developmental perspectives. The important assumption of this approach is that interaction among students increases their critical thinking, promoting personal and social growth. If students of similar ages have developmental differences, then the more advanced peers can contribute from their experiences to build new knowledge and scaffold the less advanced learners' learning process.

$>$ Cognitive elaboration perspectives. CL is effective because participants elaborate new cognitive structures in a social context. They discover new knowledge and strengthen their own mental structures.

All four perspectives should be considered in the application of CL, rather than the empirical way in which some teachers carry out this approach. It is important to know its implications and its theoretical bases to better guide the development and implementation of CL.

\subsubsection{Autonomy}

One of the most valuable benefits of collaborative learning is that it promotes the development of social, cognitive and metacognitive skills. It also fosters learners' sense of responsibility since students move from interdependence to autonomy and build new knowledge 
in a collaborative way, making contributions and receiving help from others. It permits students to make decisions about their own learning. It promotes autonomy in learning and is a long-term pedagogic goal.

The term autonomy is sometimes misunderstood when it refers to learning in isolation, working independently and alone. On reviewing different definitions about autonomous learning, different definitions were found. The information is shown in table 3.

Table 3. Different definitions about autonomy learning

\begin{tabular}{|l|l|l|}
\hline \multicolumn{1}{|c|}{ Definition } & Author & Year \\
\hline "the ability to take charge of one's own learning" & Holec & 1981 \\
\hline $\begin{array}{l}\text { "Situation in which the learner is totally responsible for all of the } \\
\text { decisions concerned with his or her learning and the } \\
\text { implementation of those decisions." }\end{array}$ & Dickinson & 1987 \\
\hline $\begin{array}{l}\text { "the techniques in order to direct one's own learning" } \\
\text { "learning in which the learners themselves take responsibility for } \\
\text { their own learning." }\end{array}$ & Thomson & 1996 \\
\hline "situations in which learners study entirely on their own." & $\begin{array}{l}\text { Benson } \\
\& \text { Voller }\end{array}$ & 1997 \\
\hline
\end{tabular}

In table 3, all of the authors agree with defining autonomy as students taking the responsibility of their own learning process. That is why collaborative learning is considered a good and pertinent approach to enhancement of autonomy as part of the social and humanistic skills that all learners should develop as future professionals. It means autonomous learners are able to choose the materials that best facilitate their comprehension, define strategies to learn, set goals and evaluate their process. Benson and Volley (1997, p.52) also mention that there are five ways in which students can develop autonomy: 
a. When students have to study entirely on their own.

b. When students need to develop skills that can be learned and applied in selfdirected learning.

c. When students need to account for an inborn "capacity" which is suppressed by institutional education.

d. When students need to exercise the "learners' responsibility" for their own learning.

e. When students are given the "right" to determine the direction of their own learning.

Autonomous learners are characterized by high levels of responsibility and interest in improving learning. They also develop a coherent set of values and principles and are involved in a still-continuing process of censure and re-evaluation (Benn 1976, cited in Candy, 1991, p. 102). An autonomous learner is able to set his/her own goals, carry out his learning process, devote time to reflect about his/her learning, and evaluate his/her process, being conscious of this process and defining ways to improve it.

On the other hand, Omaggio (1978) as cited in Wenden, 1998, pp. 41-42 defines some characteristics that identify an autonomous learner.

a. Autonomous learners have insights into their learning styles and strategies.

b. Autonomous learners take an active approach to the learning task at hand.

c. They are willing to take risks, for instance they attempt to communicate in the target language at all costs.

d. Autonomous learners are good guessers; it means a person who is able to infer and build up new concepts and knowledge from existing information. 
e. Pay attention to the form as well as to content. Students place importance on accuracy as well as appropriateness.

f. In the process of learning a foreign language, they are able to understand the target language system and make hypotheses and infer rules analyzing, applying and checking.

g. They are able to define a flexible and reflexive approach that facilitates their learning process in the target language.

Collaborative learning promotes learners' autonomy. A student is able to glean new knowledge from a group of learners in a collective way, which is helpful in promoting his autonomy in learning. This approach offers a supportive environment in which students learn to be more independent. A number of studies suggest that collaborative learning develops an interpersonal environment which promotes autonomy and responsibility in learners (Baumann, $\mathbf{J}$ \& Jones, L., (1992).

Collaborative learning offers an environment that helps learners build a community that increases the performance level of each member. Consequently, learners improve their critical thinking skills, and retention of information, while calling attention to, and developing interest in a specific topic.

CL has positive effects in the learning process because as students learn in groups, they increase their cognitive skills and are more likely to get successful results. Students are able to develop a positive attitude towards learning, increasing their self-esteem. Consequently, students' interest in the target language increases and their performance improves. Diener and Dweck (1978) state that a lack of self-esteem is likely to lead to negative attitudes towards one's capability as a learner, and to a deterioration in cognitive performance (as cited in Wenden, 1998, p. 57). 
COLLABORATIVE LEARNING IN THE COLOMBIAN EDUCATIONAL SYSTEM 20

\subsubsection{Implementing Cooperative Learning}

It is important to bear in mind that there are a number of criteria to implement CL. It is necessary to specify roles and duties for students to fulfill their task. Teachers need to ensure that all members of the groups are chosen at random or use specific criteria, Rau and Heyl (1990) state that smaller groups may lack divergent thinking styles because they contain less diversity. However, larger groups might make it difficult to ensure all members participate, so according to Salvin (1989) it is important to keep groups smaller.

- Teachers should create a positive environment and have students become acquainted with each other. It is also important to encourage politeness, respect and good behavior towards others.

- Assign academic tasks that develop a collaborative spirit and engage students in important team building activities in which they support and learn from each other.

- Agree how long the group will work together, starting with one task, then a semester, to a whole year a whole project.

- Material is important to be prepared to distribute to the group. Instructions must be clear in order for students to work together. Salvin (1989) states that for effective collaborative learning, there must be group goals and individual responsibility.

- Clarify roles for each member of the group. The teacher may have to explain and demonstrate/practice these roles previous to, and during, the activity.

\subsubsection{Conclusion}

Collaborative learning is an approach that has positive effects on participants as it is based on a social structure that facilitates students' interaction and improves their social skills. 
CL facilitates teaching since students are able to discover new knowledge through interaction. It means students learn from each other. It also has positive impact to produce a level of engagement, better than other forms of learning. On the other hand, students can explain things better to another student than a teacher to a class. CL develop teaching competences since students learn how to teach one another. CL creates a positive interdependency because students feel that they cannot succeed unless everyone in their group succeeds. Other positive benefits are that CL develops the ability to lead an activity and create responsibilities.

CL also has negative disadvantages for example, it makes students responsible for each other's learning apart from themselves. It sometimes creates chances for conflict and consequently need for conflict resolution skills. In groups of mixed ability, low-achieving students become passive, demotivated and do not focus on the task. In big groups, it is difficult for the teacher to be sure that the groups are discussing the task rather than something else. Lower ability students may feel continually looking for help rather than experiencing the role of leader and be ready to help others in the group. 


\section{Chapter 3: Research Design}

\subsection{A systematic literature review}

A systematic review is a piece of research that provides a general overview of literature on a specific topic (Boote \& Beile, 2005). Thus, a systematic review addresses much broader questions than single empirical studies. According to Baumeister and Leary (1997), a good systematic review must clarify a particular problem; identify contradictions or relations; explore reasons for these; and elaborate an overarching conceptualization instead of summarizing different points of view (Sternberg, 1991). It must also develop a theory and describe directions for further research.

The main characteristic for a systematic review is that it must be transparent and replicable; which implies a systematic search process to exploring studies that address a specific research question. It also implies presenting the findings resulting from the research. Baumeister (2013) recommends adopting the attitude of a judge and jury, rather than a lawyer. It means assuming the role of an evaluator in order to make a reasonable judgment instead of being subjective and choosing one side of an argument.

\subsection{Stages in conducting a systematic review}

To develop this research project, the stages described in the following table were considered. First, a question was formulated; then relevant research studies were selected in order to analyze their data and finally, their results were analyzed and summarized to build up the systematic review (Baumeister\& Leary, 1997; and Cooper, 2008). Table 4. shows the stages to conduct a systematic review. 
Table 4. Stages to Conduct a Systematic Review according to Baumeister\& Leary, 1997; and Cooper, 2008)

\begin{tabular}{|l|l|}
\hline STAGES & PROCESS \\
\hline Scoping & $\begin{array}{l}\text { Think about the audience, formulate one or more research questions as } \\
\text { to clarify whether the planned systematic review has already been done. }\end{array}$ \\
\hline Planning & $\begin{array}{l}\text { Find as many potentially relevant articles as possible to include, make } \\
\text { an exhaustive search of the most representative studies that have been } \\
\text { conducted on the topic of interest. }\end{array}$ \\
\hline Identification (searching) & $\begin{array}{l}\text { Search at least two different (relevant) electronic databases. } \\
\text { Inspect the results and conduct additional searches to ensure you have } \\
\text { located all relevant publications. }\end{array}$ \\
\hline Screening & $\begin{array}{l}\text { Export references to a citation manager to collate the search results. } \\
\text { Read the Title and/or Abstract of identified work. }\end{array}$ \\
\hline Eligibility & $\begin{array}{l}\text { Sift the full-text version of potentially eligible articles and extract } \\
\text { relevant information to be included. }\end{array}$ \\
\hline
\end{tabular}

\subsection{Research Paradigm and Methodology}

After following the steps mentioned above, the type of research was defined. This is a qualitative research study because the studies found are methodologically diverse in order to make a meta-analysis giving precise description. Marshall (1999) defines qualitative research as a process of trying to gain a better understanding of the complexities of human experience.

Qualitative research is especially effective in obtaining culturally specific information about any topic or specific theme of interest.

Family Health International (2005), defines qualitative research as the ability to provide complex textual descriptions about people's experiences in any given research issue. It means that qualitative research helps to interpret and understand the complexity of a given situation and the implications of qualitative data. 
To carry out this research, a variety of articles were considered because in Colombia a lot has been published during the last two decades. The researcher conducted this research for 4 months by using databases: EBSCO, PUBLINDEX, SCOPUS, Scielo, Latindex, RedALyC, Dialnet ResearchGate, DOAJ, as it is shown in table No 6. The key words about the topic, collaborative learning second language, bilingualism in Colombia educational system and approach, were introduced. The database provided the corresponding abstracts and keywords. R.A.E (Resumen Analitico Especializado) was imperative to find a synthesis of the concepts, approaches, proposals or ideas, following the structural organization from the original text.

At first, the research was only focused on general theories about CL. It was easy to find the information as there was a great quantity of material such as books and articles that contain this topic. This information was used to build the theoretical framework. After, an in-depth reading was carried out and the most interesting points of view according to the experts were summarized. Then, the search was focused on research projects conducted in Colombia during the last two decades. Only those articles related to CL in the context of foreign language learning were chosen.

The purpose of selecting articles written as a product of any research study was to contextualize the research and help teachers to understand how this approach could be implemented in any Colombian educational context. It should be considered that there are local factors in the Colombian education system that affect the implementation of any approach. Therefore, it is significant for teachers to know how this approach has been implemented in educational contexts similar to the ones they experience. 
All the articles were reviewed and filtered according to the pre-established criteria in order to extract the relevant information. Each article was reviewed considering the title, research question, objectives, context, theoretical constructs, data collection instruments, methodology, findings, and conclusions.

Table 5. Criteria to select the articles

\begin{tabular}{|l|l|}
\hline \multicolumn{1}{|c|}{ Criteria } & \multicolumn{1}{c|}{ Reasons } \\
\hline Research Articles & $\begin{array}{l}\text { Articles that show results of research in Collaborative } \\
\text { Learning }\end{array}$ \\
\hline Context & Foreign language learning context \\
\hline Place & Research conducted in Colombia \\
\hline Time & From 2000 to 2016 \\
\hline Research design & Qualitative, Quantitative and Mix methods \\
\hline Title & $\begin{array}{l}\text { Title of the articles that show close relationship to the } \\
\text { topic }\end{array}$ \\
\hline Research question & Closely to find response to some troubles in education \\
\hline Objectives & That enlighten a way in which research was proceed \\
\hline Theoretical constructs, & $\begin{array}{l}\text { To know definitions, studies and opinions that } \\
\text { constitute a good theory for this research }\end{array}$ \\
\hline Data collection instruments, & To identify strategies used \\
\hline Findings, and conclusions & To identify the relevant founding \\
\hline
\end{tabular}

Twenty-five (25) articles were finally selected; and then ten (10) were considered relevant for this systematic review. The information was extracted to a spreadsheet (see appendix 2). Then an in-depth review was made, considering the research questions and objectives defined in this research. This means the research question and objectives were related to the purpose of this research.

Considering the inclusion and exclusion of the criteria, the studies found provided the theoretical framework underpinning the concept of CL and the differences with CL and Peer to 
Peer Learning (PPL). The evolution of CL in CNL and CSCL was also included. The studies that provided evidence related to the use of this approach, including their contributions on current teaching situations were also identified.

\subsection{Data collection instrument and validation}

For this research, I defined instrument databases registers and R.A.E (Resumen Analitico Especilizado) where I found articles related to the studied topic. And instruments for the taxonomy and categorization of the Literature Review were also considered, this leads to the development of the theoretical framework, theoretical construct and conceptual framework of the articles that were selected. A literature map was also used to express relationships between ideas, arguments and concepts (See appendix 5). It was used as a tool to develop critical and analytical skills and to help me understand relationships in the concepts that were included in the articles used for this research. All the instruments were first piloted in order to verify its usefulness, then they were validated with experts in research who made suggestions to adapt them to my study.

\subsection{Ethical considerations}

In order to develop this research, the following considerations were considered, bearing in mind what Bryman and Bell (2007) state the most important principles related to ethical considerations in dissertations. First, I considered the adequate level of confidentiality of the research data used for this study. Also, the use of any type of ambiguous information was avoided, as well as representation of primary data findings that were biased in any way. For this research, articles carefully selected from indexed magazines were used that had academic consistency, which means the information they presented had a high grade of plausibility. 


\subsection{Researcher's role}

According to Denzin \& Lincoln (2003), my role as a researcher was an instrument of data collection. This means that the data is mediated trough the human instrument rather than through inventories, questionnaires or machines. On the other hand, according to Creswell, (2007) the researcher's role in qualitative research is critical, as he or she collects data and implements analysis. My role in this study was as an observer participant because I was the primary instrument for data collection and analyzing that data, coded and analysis the data to identify the emerging concepts and patterns. 


\section{Chapter 4: Results and Data Analysis}

\subsection{Introduction}

This chapter includes an explanation of the screening procedures applied to the studies that were obtained for this review. It presents a systematic review of the studies carried out during the last two decades in Colombia on collaborative learning. In addition, this review focuses on foreign language learning. According to the criteria established, 10 articles were analyzed in the present chapter.

\subsection{Results of the database search}

At the beginning of the search, more than 500 articles related to CL were found. However, taking into account the pre-established search criteria (see table 5.), 248 reports were excluded as they did not focus on foreign language learning. Some of the articles referred to the implementation of CL in teaching mathematics or chemistry in university settings, the impact of CL in the development of new knowledge and success of their academic development. Thus, those articles were not relevant for the purpose of this study. The 252 articles were analyzed, it was found that most of them corresponded to researches done before year 2000. The next step was to select the ones done during the last two decades, and 25 were found. However, 15 were done in other countries. Finally, 10 were analyzed because they fit the criteria. 
Figure 2: Selected Articles

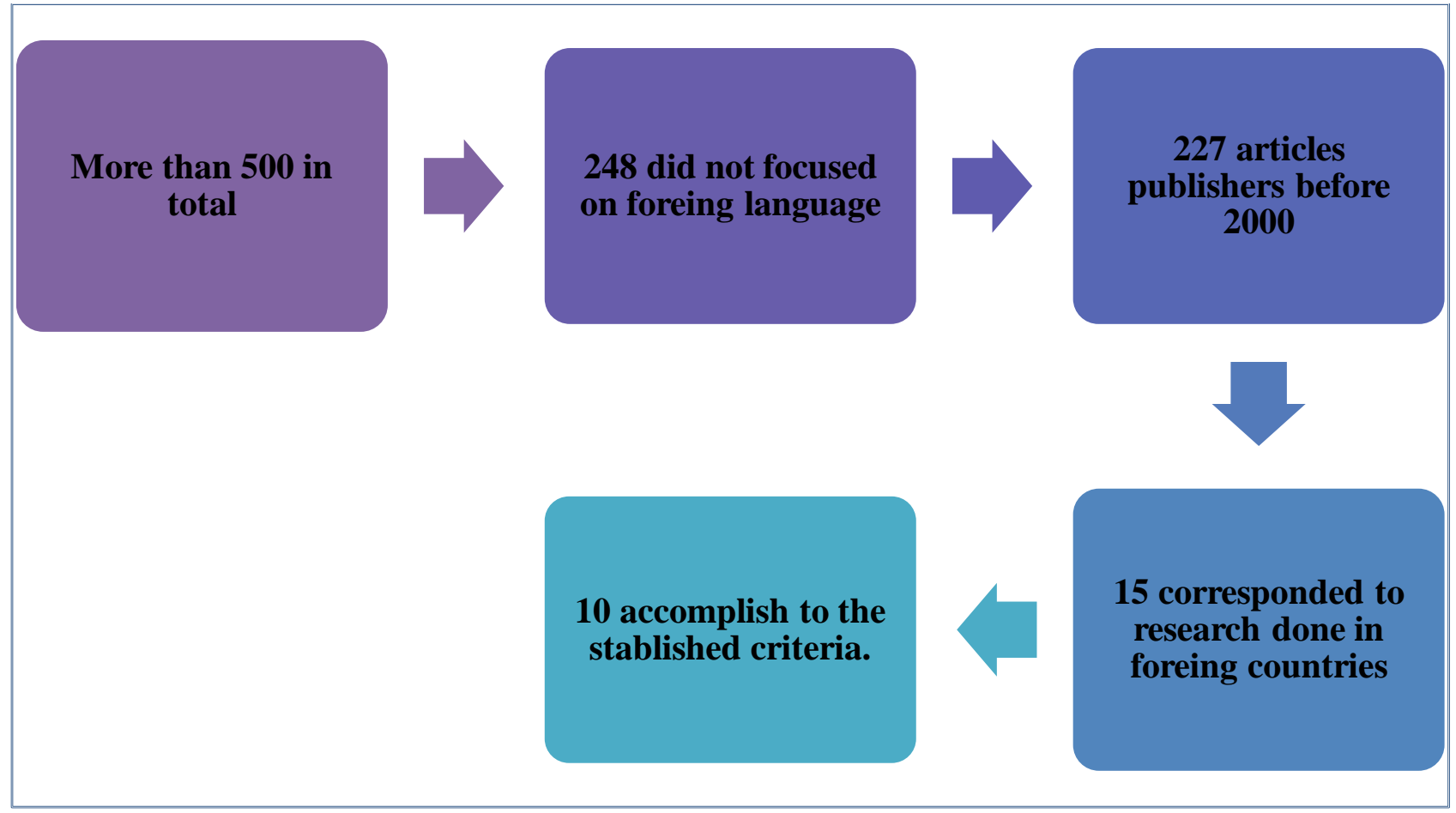

Table 6. List of databases consulted

\begin{tabular}{|l|l|}
\hline \multicolumn{1}{|c|}{ DATABASES } & \multicolumn{1}{c|}{ DEFINITION } \\
\hline Google Scholar & Abstracts and technical reports about this topic of research. \\
\hline Scopus & $\begin{array}{l}\text { The largest database of citations and abstracts of scientific journals, } \\
\text { books and conference proceedings. }\end{array}$ \\
\hline Scielo & $\begin{array}{l}\text { Electronic library that selects collection of scientific journals from } \\
\text { all areas of knowledge. }\end{array}$ \\
\hline Latindex & Scientific Journals of Latin America and the Caribbean, Spain \\
\hline Publindex & National scientific journals \\
\hline RedALyC & $\begin{array}{l}\text { Scientific Journals of Latin America and the Caribbean, Spain and } \\
\text { Portugal. }\end{array}$ \\
\hline Researchgate & Find abstracts and reports about research \\
\hline Dialnet & scientific publishing in Spanish \\
\hline DOAJ & $\begin{array}{l}\text { Online directory that provides access to quality open access, peer- } \\
\text { reviewed journals. }\end{array}$ \\
\hline
\end{tabular}


There were 25 articles that were pertinent for this study; however, 15 of them corresponded to research studies done in other countries and this systematic review aims to include studies carried out in Colombia, therefore, only 10 articles were analyzed. As it was mentioned before, CL implies the mutual engagement of participants and combines everyone's efforts to figure out a task or a work. Cooperative learning implies individual work in which each subject takes responsibility for a specific task that is part of a project or a product. Both of them are group learning approaches that imply that students take an active role in the class; and both of them suggest social responsibility and social skill development.

The conclusion was that these two approaches have different methodological and epistemological implications. The table below illustrates the reason why they were explored.

Table 7. Differences between Collaborative and Cooperative Learning

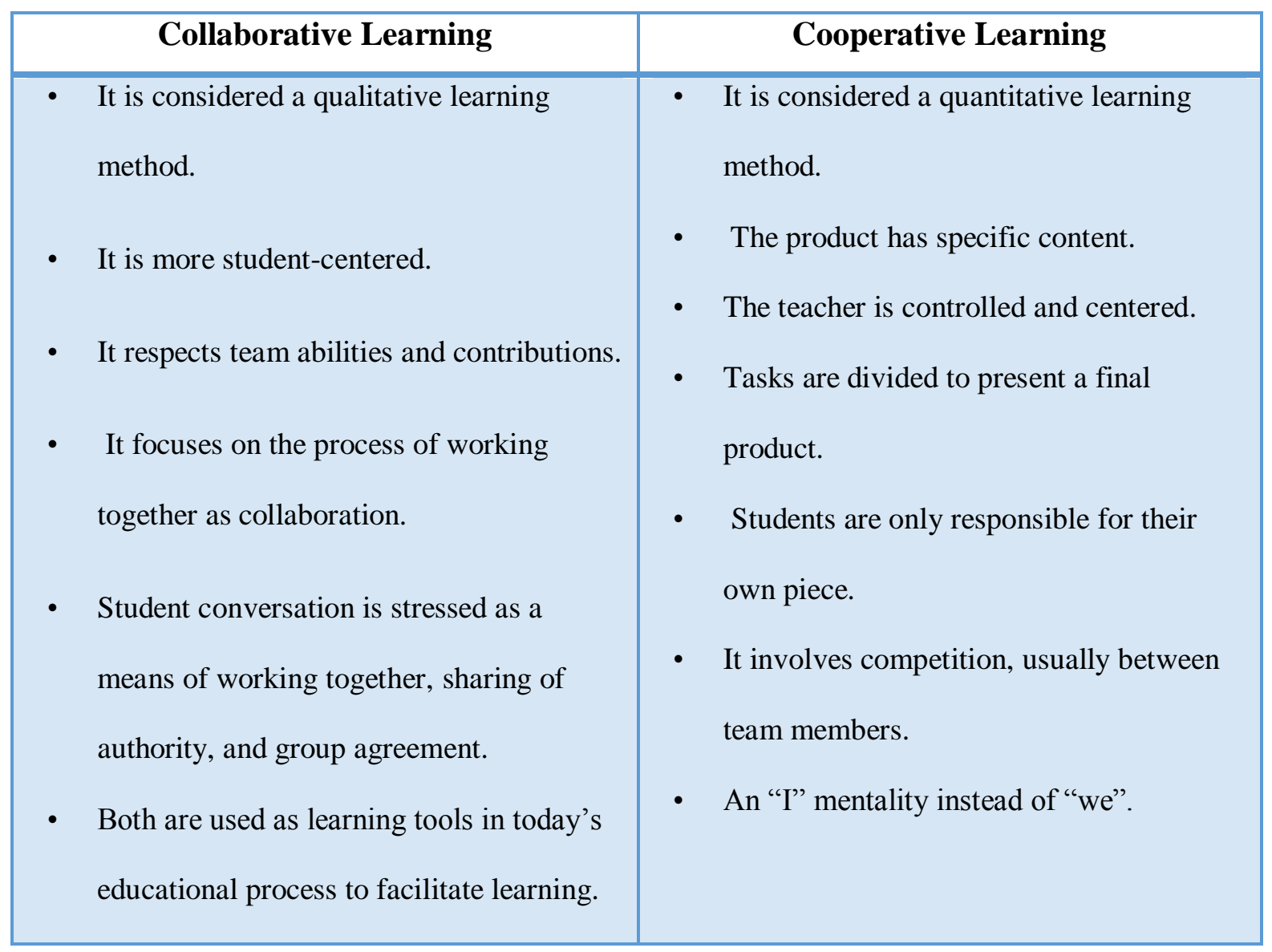


- Both require knowledge and social skills.

- These methods include placing learners into teams and groups.
- Cooperative learning is more teachers oriented.

- As for collaborative learning, students are in control of their own learning

- Cooperative learning tends to facilitate competition between members.

The present study focuses on Collaborative Learning because according to the literature review, CL grants much more autonomy and students are in control of their learning process instead of the teacher. It means that teachers are guides and learners do not have to work alone. The final task is the result of a collaborative process.

According to Mittan, cited in Ede, L., \& Lunsford, A. A. (2001), "collaboration is a cross-fertilization of ideas, the energizing discussion among people with common interests and goals, the shared sense of accomplishments when those goals are reached".

It was important to take into consideration that working collaboratively implies a preparation of learners for the future. CL is a way to work together while using our individual abilities and no one team member takes on all the leadership and responsibilities.

\subsection{Characterization of the studies}

The criteria established earlier in the protocol designed restricted the selection of articles to those focused-on contents related to the research question of this thesis: What is the general definition of this approach and its implications according to the literature review included in the selected articles? As it was mentioned at the beginning, an increasing interest in investigating 
the impact of collaborative learning in different educational contexts has arisen in Colombia. The articles reviewed in the different databases demonstrated that researchers have successfully implemented this approach.

To select the articles, some criteria were established in order to find the final ones that were thus analyzed, as it is shown in table 8. More specifically, the articles needed to address the topic of CL in the context of foreign language teaching and learning in Colombia during the last two decades. Other criteria of inclusion required articles with qualitative, quantitative, or mixed methods. Articles to be included in the review needed to focus only on populations located in the educational sector. Action research projects were also selected to identify the impact of implementing this approach across different levels of education.

Table 8. Characterization of the studies

\begin{tabular}{|c|c|c|}
\hline CRITERIA & INCLUSION & EXCLUSION \\
\hline Content & $\begin{array}{l}\text { Collaborative learning for } \\
\text { teaching English as a foreign } \\
\text { language. }\end{array}$ & $\begin{array}{l}\text { - Collaborative learning other subjects, e.g. math. } \\
\text { - Collaborative learning for teaching other } \\
\text { languages, e.g. French } \\
\text { - Studies done in other countries, e.g. China. }\end{array}$ \\
\hline Setting & All educational levels. & Non- formal education. \\
\hline Methodology & $\begin{array}{l}\text { Qualitative method studies } \\
\text { Quantitative method studies } \\
\text { Mixed method studies } \\
\text { Action research }\end{array}$ & Evidence of the impact. \\
\hline $\begin{array}{l}\text { Type of } \\
\text { publication }\end{array}$ & $\begin{array}{l}\text { Journal articles of studies done } \\
\text { in Colombia. }\end{array}$ & $\begin{array}{l}\text { Publications that were not related with the topic of } \\
\text { this study; for example: autonomous learning, } \\
\text { cooperative learning. } \\
\text { Publications that report impact on other subjects. }\end{array}$ \\
\hline $\begin{array}{c}\text { Year of } \\
\text { publication }\end{array}$ & During the last two decades & Articles published before year 2000 \\
\hline
\end{tabular}


COLLABORATIVE LEARNING IN THE COLOMBIAN EDUCATIONAL SYSTEM 33

\subsection{Interpretation of findings}

As it was mentioned before, there was an interest in identifying the evidences of implementing CL and the outcomes of studies done in Colombia. This review demonstrated that the entries of CL articles in different databases generated a wide number of results. However, the number of entries was significantly reduced when the concept studies dealt directly with CL in the foreign language learning context.

It was important to identify some general characteristics of the studies regarding CL bearing in mind, for instance, years and place of production, population, and educational settings.

\subsection{Deep analysis}

This section presents a deep analysis making a complete description of the population and sampling where CL has been implemented such as teenagers, young adults and adults, in the same way it is presented a description of the context where research studies were done, primary and secondary schools, private and state institutions. Finally, it is present the skills that according to the researchers found, have been develop using CL such as cognitive skills, social skills and interpersonal skills.

\subsubsection{Population:}

It is worth noticing that Collaborative Learning has been applied in different contexts and in all levels of education. Eight research studies were done in primary and secondary schools in Colombia. They were done in state schools and private schools with students of different ages. There were two research studies done in virtual and distance education and six in undergraduate programs. It means that CL is an approach that can be used in any level of education with students of different ages and different social strata since some of the research projects 
mentioned in annex 2 were done in private institutions and others in public institutions. The table below shows the impact that the implementation of CL had on different groups of students.

4.5.1.1 Teenagers: Six studies done with teenagers from secondary schools were found.

Table 9. Implementation of Collaborative Learning

\begin{tabular}{|l|l|l|}
\hline TITLE & POPULATION & \multicolumn{1}{|c|}{ FINDINGS } \\
\hline $\begin{array}{l}\text { Work in the Development } \\
\text { of Elementary Students' }\end{array}$ & $\begin{array}{l}\text { Writing Skills } \\
\text { from Corporación } \\
\text { Colegio San } \\
\text { Bonifacio de las } \\
\text { Lanzas, a private } \\
\text { bilingual school in } \\
\text { Ibague Colombia. }\end{array}$ & $\begin{array}{l}\text { Students helped each other and carried out } \\
\text { different task as a whole group. Students learned } \\
\text { about peer-correction and peer-work while } \\
\text { developing the task. We can state that this } \\
\text { outcome was meaningful and spontaneous } \\
\text { learning took place among the students while } \\
\text { they helped each other. Students seemed to be } \\
\text { more decisive as to what they wanted to do } \\
\text { while working and being part of a group. }\end{array}$ \\
\hline $\begin{array}{l}\text { teams: a strategy to foster } \\
\text { self-directed language } \\
\text { learning in A1 Colombian } \\
\text { students }\end{array}$ & $\begin{array}{l}\text { Four state schools in } \\
\text { Colombia, } \\
\text { 35 participants 11-19 } \\
\text { years old. }\end{array}$ & $\begin{array}{l}\text { As a general conclusion, it can be stated that the } \\
\text { subjects from this study showed positive } \\
\text { changes in their language learning performance } \\
\text { and level of motivation after the pedagogical } \\
\text { intervention. As a result of implementing } \\
\text { Communicative Language Teaching strategy the } \\
\text { participants became self-directed learners. }\end{array}$ \\
\hline $\begin{array}{l}\text { 2ollaborative learning } \\
\text { in a collaborative learning } \\
\text { environment }\end{array}$ & $\begin{array}{l}\text { Students from } \\
\text { eleventh grade from } \\
\text { a private school in } \\
\text { Colombia. }\end{array}$ & $\begin{array}{l}\text { Collaborative Learning was an opportunity for } \\
\text { students to help each other to construct meaning } \\
\text { and knowledge. They worked on tasks that } \\
\text { demanded analyzing, planning, acting and } \\
\text { reflecting on their work as a tool to measure } \\
\text { their capacity to work with others, as well as } \\
\text { their abilities and contributions as regards } \\
\text { common tasks. }\end{array}$ \\
\hline
\end{tabular}

\subsubsection{CL with teenagers}

According to the findings shown in the table above, it seems that CL offers meaningful experiences for learners and for teachers as well since it allows teachers to create a better 
environment for the learning process. Smith and Macgregor (1992) state that nowadays, CL is seen as a powerful tool that offers meaningful experiences for students and teachers. Here learning as a group is the manner that stimulates other learning processes. According to these authors, teachers are not the ones that possess all the knowledge; teachers rather encourage students to succeed in their learning processes. Findings in the following articles show that teachers successfully implemented CL.

\subsubsection{Young Adults and Adults}

Table 10. Articles about Collaborative learning

\begin{tabular}{|l|l|l|l|}
\hline $\begin{array}{l}\text { TITLE OF } \\
\text { ARTICLES }\end{array}$ & POPULATION & \multicolumn{1}{|c|}{ FINDINGS } & AUTHORS \\
\hline $\begin{array}{l}\text { Collaborative Project } \\
\text { Work Development } \\
\text { in a Virtual } \\
\text { Environment with } \\
\begin{array}{l}\text { Low-Intermediate } \\
\text { Undergraduate } \\
\text { Colombian Students }\end{array}\end{array}$ & $\begin{array}{l}\text { A virtual English } \\
\text { language learning } \\
\text { program at a public } \\
\text { university in } \\
\text { Bogotá (Colombia). }\end{array}$ & $\begin{array}{l}\text { CL helped students to } \\
\text { bridge the gap of isolation } \\
\text { generated by distance in } \\
\text { virtual environments, } \\
\text { bringing more interaction, } \\
\text { knowledge sharing, and } \\
\text { responsibility. }\end{array}$ & $\begin{array}{l}\text { Yakelin Salinas Vacca* } \\
\text { Universidad Nacional } \\
\text { de Colombia and } \\
\text { Fundación } \\
\text { Universitaria Los } \\
\text { Libertadores, Bogotá, } \\
\text { Colombia }\end{array}$ \\
\hline $\begin{array}{l}\text { Collaborative Work } \\
\text { as an Alternative for } \\
\text { Writing Research } \\
\text { Article }\end{array}$ & $\begin{array}{l}\text { A group of nine } \\
\text { students in their } \\
\text { tenth semester in } \\
\text { the Electronics } \\
\text { Engineering } \\
\text { Faculty at } \\
\text { Universidad Santo } \\
\text { Tomas. }\end{array}$ & $\begin{array}{l}\text { Most students showed a } \\
\text { positive attitude during the } \\
\text { development of each } \\
\text { workshop and enjoyed } \\
\text { working in groups. } \\
\text { They helped each other; } \\
\text { and also, they acquired } \\
\text { specific roles conducting } \\
\text { significant negotiations. } \\
\text { CL encouraged the } \\
\text { participants to take on } \\
\text { different work roles, such } \\
\text { as leaders, harmonizers, } \\
\text { facilitators, compromisers, } \\
\text { among others. }\end{array}$ & $\begin{array}{l}\text { Medina*1 Universidad } \\
\text { Pedagógica y } \\
\text { Tecnológica de } \\
\text { Colombia, Tunja, } \\
\text { Colombia Eliana Edith } \\
\text { Roberto Flórez*2 }\end{array}$ \\
$\begin{array}{l}\text { Universidad Santo } \\
\text { Tomás - Tunja, } \\
\text { Colombia }\end{array}$
\end{tabular}




\begin{tabular}{|c|c|c|c|}
\hline $\begin{array}{l}\text { Making Sense of } \\
\text { Critical Pedagogy in } \\
\text { L2 Education } \\
\text { Through a } \\
\text { Collaborative Study } \\
\text { Group }\end{array}$ & $\begin{array}{l}\text { Eleven members } \\
\text { who all had } \\
\text { different levels of } \\
\text { teaching } \\
\text { experience (from } \\
\text { the Bachelor's and } \\
\text { Master's program } \\
\text { in Foreign } \\
\text { Language } \\
\text { Teaching) }\end{array}$ & $\begin{array}{l}\text { CL created a positive } \\
\text { learning environment } \\
\text { because it decreased the } \\
\text { effects of anxiety often } \\
\text { produced by complex } \\
\text { content, and abstract } \\
\text { concepts or ideas. Students } \\
\text { could express their fears, } \\
\text { ideas, biases, or lack of } \\
\text { understanding. }\end{array}$ & $\begin{array}{l}\text { Paula Andrea Echeverri } \\
\text { Sucerquia } \\
\text { Sebastián Pérez } \\
\text { Restrepo } \\
\text { Universidad de } \\
\text { Antioquia, Medellín, } \\
\text { Colombia }\end{array}$ \\
\hline $\begin{array}{l}\text { Collaborative Work } \\
\text { with Wikis in the } \\
\text { setting monitoring } \\
\text { language learning } \\
\text { 4.5.1.4 objectives }\end{array}$ & $\begin{array}{l}15 \text { adult learners at } \\
\text { intermediate level } \\
\text { B1 according to the } \\
\text { Common European } \\
\text { Framework of } \\
\text { Reference (CEFR) } \\
\text { at a language } \\
\text { institute. }\end{array}$ & $\begin{array}{l}\text { Students participated in the } \\
\text { wikis and helped each other } \\
\text { to make contributions. } \\
\text { Students could assess the } \\
\text { outcomes of their language } \\
\text { objectives and they } \\
\text { accomplished their } \\
\text { expected languages } \\
\text { learning process. }\end{array}$ & $\begin{array}{l}\text { Santana Prieto, Boris } \\
\text { Ernesto } \\
\text { Universidad de la } \\
\text { Sabana }\end{array}$ \\
\hline $\begin{array}{l}\text { Collaborative } \\
\text { Learning and } \\
\text { Autonomy in EFL } \\
\text { University Students }\end{array}$ & $\begin{array}{l}\text { Students from the } \\
\text { fourth semester of } \\
\text { Veterinary } \\
\text { Medicine at a local } \\
\text { institution in Tunja, } \\
\text { Boyacá. }\end{array}$ & $\begin{array}{l}\text { Students enjoyed working } \\
\text { collaboratively. } \\
\text { Students increased oral } \\
\text { interaction in the foreign } \\
\text { language and made their } \\
\text { learning process } \\
\text { meaningful. } \\
\text { Students gradually began to } \\
\text { diminish their fear of } \\
\text { talking and took the risk of } \\
\text { participating and } \\
\text { interacting in the target } \\
\text { language. }\end{array}$ & $\begin{array}{l}\text { Molina Farfán, Zaida } \\
\text { Carolina } \\
\text { Universidad de la } \\
\text { Sabana }\end{array}$ \\
\hline
\end{tabular}

\subsubsection{CL with young adults and adults}

After analyzing the data, it can be concluded that CL was implemented with young adults and adults in face-to-face, virtual, and distance programs in different universities and institutions. In all these experiences, students were motivated to work in groups instead of working individually. Having a positive attitude is essential in the configuration of collaborative practices 
that differ from individualistic and competitive work (Curtis \& Lawson, 1999). Studies also showed that students changed their attitude toward English as they could reduce their anxiety and felt confident to express their fears, doubts and questions.

One of the studies in table 5 was done with students in a virtual course. The results showed that students were motivated to participate in wikis. The experience was successful with those students, so it proves that CL could be implemented in virtual environments. The effects were equally positive also in face-to-face courses. In accordance with Stacey (1999), the studies held at a university in Bogotá show that students were able to learn even when they were not present at their university campus.

One of the most relevant findings here was that students' reduced anxiety which is a common factor that prevents the success of the process. It was noticed that CL helped to create a supportive environment in which students were less stressed and felt more confident in class. According to Worde (2003), when students have no friends in class, they are "more selfconscious". Working in groups is a good opportunity to increase interaction with their classmates. Based on the findings, there are always weak and more advanced students in a class. Weak students are usually alone because they are not confident about their English skills and communicative performance; while advanced students are the ones who commonly have the leading role in the class.

\subsubsection{Context}

Regarding the context, five of the CL research studies were done in primary and secondary schools, in both private and state institutions. Three of these studies were carried out 
in university settings that included both a bachelor program and a master's program. Finally, two of these studies were carried out in virtual and distance programs.

It means that $\mathrm{CL}$ is an approach that could be implemented in all educative contexts, in spite of the differences, and the implications that each one might have. In virtual education, for example, students do not have the opportunity to interact face to face; however, the implementation of CL was successful according to the report made by researchers.

It is well known that there are noteworthy differences among primary, secondary and tertiary education as each one has a different purpose and they focus on different kinds of population. Each one has different methodological implications because of the age, interests and goals of the learners. Nevertheless, CL was implemented in all of these groups and it was successful according to the reports presented and reviewed.

There were important evidences that showed that CL can be implemented by teachers in all contexts such as classroom, virtual, distance, public and private sectors and with students of all ages. In all the reports reviewed, researches showed the positive impact, benefits, and the advantages of its implementation.

Figure 3. Collaborative Learning Implementation

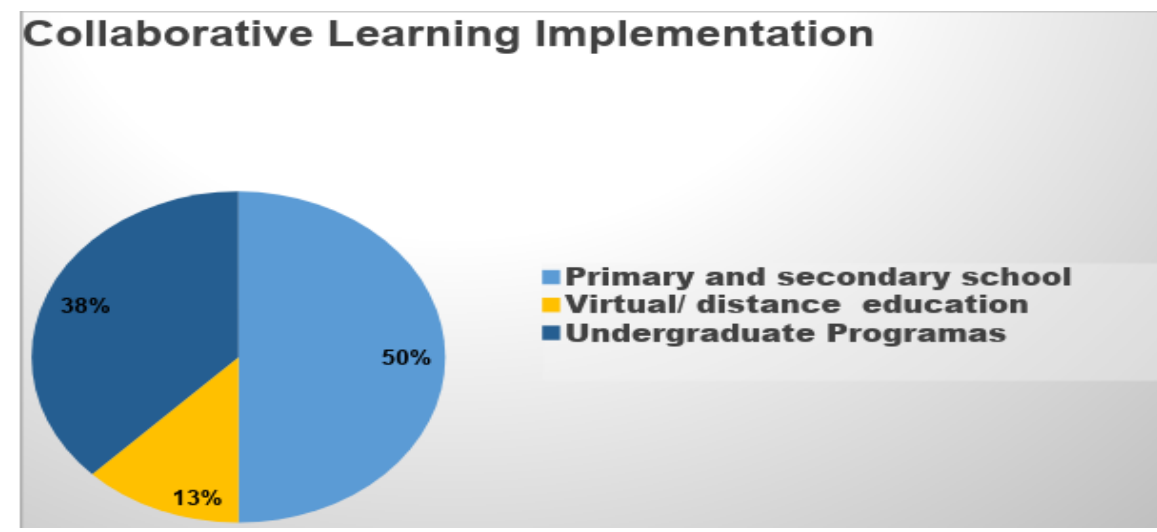




\subsubsection{Communicative skills}

As it was mentioned before, the articles were chosen because they met the initial criteria. In the field of teaching English as a foreign language, it was noticed that this approach was used to foster writing and reading, as it is shown in the table below. Numerous advantages were reported by teachers. There were six studies that show the enhancement of one of these skills, writing, showing the benefits of CL when teaching English through this specific skill.

Table 11. Findings about Collaborative learning

\begin{tabular}{|l|l|l|}
\hline TITLE & $\begin{array}{l}\text { COMMUNICATIVE } \\
\text { SKILL }\end{array}$ & FINDINGS \\
\hline $\begin{array}{l}\text { The Role of Collaborative } \\
\text { Work in the Development } \\
\text { of Elementary Students' } \\
\text { Writing Skills }\end{array}$ & Writing & $\begin{array}{l}\text { Students improved their oral language and writing. } \\
\text { Students helped each other and shared learning } \\
\text { strategies. } \\
\text { Students also worked together to make the } \\
\text { understanding of a specific topic easier. }\end{array}$ \\
\hline $\begin{array}{l}\text { The Role of Collaborative } \\
\text { Work in the Development } \\
\text { of Elementary Students' } \\
\text { Writing Skills }\end{array}$ & Writing & $\begin{array}{l}\text { Students improved their writing skills } \\
\text { And they received friendly feedback }\end{array}$ \\
\hline $\begin{array}{l}\text { Collaborative Work as an } \\
\text { Alternative for Writing. } \\
\text { Research Article }\end{array}$ & Writing & $\begin{array}{l}\text { Students were motivated. } \\
\text { As they worked as a team. }\end{array}$ \\
\hline
\end{tabular}

\subsection{Categories of analysis}

After analyzing the information and findings in the articles selected, three main categories were defined. According to these studies, CL impacted on students' learning since cognitive, social, and interpersonal skills were improved. 
As it is shown in figure No 03, three categories were identified, cognitive skills development; social skills development and interpersonal skills development.

Figure 4. Categories and subcategories

\section{Cognitive skills development}

Improving language skills

Developing meta-cognitive skills

\section{Social skills development}

\section{Interpersonal skills development}

Awareness development

Self-confidence

\subsubsection{Cognitive skill development}

According to the studies, students were able to improve two important aspect as a result of using CL. They, in fact, improved their language skills, specifically reading and writing. Likewise, they developed meta-cognitive skills.

\subsubsection{Improving language skills.}

According to these studies, CL helped students to improve their language skills as it was mentioned in the section before. It is important to state that CL was applied to improve mainly writing and reading skills. The researchers also mentioned that when students were involved in 
collaborative activities, they had the opportunity to reflect about their performance during the activity.

Students had the opportunity to share ideas with their partners and they were able to share ideas with each other. In addition, they were able to work together to accomplish shared goals such as doing the assignments collaboratively rather than competitively. Teachers also stated that one of the most important goals was that their students improved their reading and writing skills because they had the chance to ask for help and received support from their partners. Some of them mentioned that their students overcame their weaknesses. In the case of those less advantaged students, not only did they improve their skills; but they also got rid of fears and felt more confident. As a result, they helped each other, with the more advanced helping their partners. In that way, they could work as a team in order to achieve a specific task and reach a goal.

\subsubsection{Developing metacognitive skills}

Another important outcome that the studies mentioned was the development of metacognitive skills. It seems when students interact with each other, they develop metacognitive skills. Carrell (1998) states that in CL, meta-cognition is a very important factor that affects learning. Carrel (1998, p. 4) defines metacognition as "cognition of cognition... thinking about thinking... and learning about learning". When students interact in groups, they develop autonomy and are more aware of the way they learn. Golombek (2003) explains that cognitive development occurs in the movement from social mediation to internal mediation; that is, internalization. According to the studies, CL facilitates the acquisition of meta-cognitive skills. 
COLLABORATIVE LEARNING IN THE COLOMBIAN EDUCATIONAL SYSTEM 42

\subsubsection{Social skills development}

According to the research studies, CL promotes social interaction when students share ideas with their partners, as they have the chance to listening to one another and express their own ideas. Students take advantage of this interaction and reinforce social skills, demonstrating that this approach is more than a matter of group activity. The characteristics already mentioned create the perfect environment for learning under agreed parameters, receiving useful and friendly feedback, sharing and respecting ideas. It has been proven that learners feel more confident when they receive feedback from their friends than from the teacher.

In a research done by Céline Buchs and Fabrizio Butera in the University of Geneva, it was proven that CL allows to identify that social skills development is crucial for group work to be efficient in terms of cognitive/academic results and have an important impact on the development of social skills.

\subsubsection{Interpersonal skills development}

One of the positive aspects found and cited in the research studies was something that could be called interpersonal skills development. In these research projects, CL helped students be more confident in reaching their goals. It turned up into a better behavior and better interpersonal conditions that facilitated their learning process. As it was pointed out in one of the articles, CL can be considered as an opportunity to build up a safe learning environment for students because they can collaborate, interact and communicate effectively, among them by developing interpersonal skills (Gillies, 2007).

\subsubsection{Awareness development}


Three of the studies mentioned concluded that students were more aware of their mistakes in their writing process and were more decisive when doing writing activities. Therefore, CL had an important impact on students' language learning process. Students had the opportunity to evaluate their own learning process using reflection to make self-comparisons. It can be stated that awareness helped students to overcome their weakness and create better and successful knowledge.

Students also developed positive interdependence since they improved their individual responsibility for their learning when they performed a collaborative learning task. In addition, they respected the opinions of others. It could be concluded that CL strengthens students' efforts to overcome their learning language barriers, co-constructing and transforming their knowledge in order to guide them into a deeper understanding (Hurd, 2005).

\subsubsection{Self-confidence}

Another positive aspect mentioned as a result of CL was that students gained selfconfidence, which is considered one of the main sources of motivation that regulates students' behavior. Gardner (2001) claims that "the higher the level of confidence students have about their own skills, the more frequent contact with the target language and higher achievement can be expected" (p.7). Self-confidence is one of the most important factors contributing to the increase and enhancement of students' motivations. These results showed that the use of CL has a direct influence on self-confidence. It reduces the anxiety that students experienced as the result of learning and practicing a foreign language. Therefore, students felt more confident about their process, demonstrating the benefits of students' languages learning process.

\subsection{Answering Initial Questions}


As it was mentioned at the beginning of this paper, this project was developed following two steps, the first one was to check the concepts about CL according to the experts.

\section{What is the general definition of this approach according to the literature review presented in the academic articles taken from well- known authors?}

After reviewing the definitions included in the articles selected, CL is defined as an instructional approach that requires small groups of learners working together to achieve a common goal (Laal \& Ghodsi, 2011). A definition from Forsyth (2006), states that CL refers to working in groups of two or more individuals who are linked to one another by social relationships. All the articles were based on this definition and researchers agreed that CL is an approach with valuable advantages such as the improvement of social and cognitive skills and self-confidence, as it has been mentioned previously. Besides, the articles reported CL to be an active process in which all of the participants provide meaningful ideas for projects or tasks to be carried out.

According to the 16 articles that were reviewed, the following definitions about collaborative learning were found.

Table 12. Definitions about Collaborative Learning

\begin{tabular}{|l|l|}
\hline \multicolumn{1}{|c|}{ Study } & \multicolumn{1}{c|}{ Definition } \\
\hline $\begin{array}{l}\text { Smith and Macgregor } \\
(1992) .\end{array}$ & $\begin{array}{l}\text { Collaborative Learning is seen as a powerful tool that provides meaningful } \\
\text { experiences for students and teachers, in which learning as a group is the motor } \\
\text { that impulses other learning processes. }\end{array}$ \\
\hline
\end{tabular}




\begin{tabular}{|l|l|}
\hline Dillenbourg (1999). & $\begin{array}{l}\text { CL involves interactions that are highly characterized by negotiation. In order } \\
\text { for these interactions to in fact happen, there must be three elements: } \\
\text { interactivity, synchronicity, and negotiability. Interactivity depends on the } \\
\text { degree to which the interactions influence the peers' cognitive processes, more } \\
\text { than on the number of interactions. }\end{array}$ \\
\hline $\begin{array}{l}\text { Artz and Newman } \\
\text { (1990) }\end{array}$ & $\begin{array}{l}\text { CL is seen as a small group of people who work as a team to solve a problem, } \\
\text { complete a task, or achieve a common goal. }\end{array}$ \\
\hline $\begin{array}{l}\text { Srinivas, H. (2011) } \\
\text { CL is an educational approach to teaching and learning that involves groups of } \\
\text { learners working together to solve a problem, complete a task, or create a } \\
\text { product. }\end{array}$ \\
\hline $\begin{array}{l}\text { Knowledge is } \\
\text { constructed, } \\
\text { discovered, and } \\
\text { transformed by students } \\
\begin{array}{l}\text { Johnson, Johnson \& } \\
\text { Smith (2003). }\end{array}\end{array}$ & $\begin{array}{l}\text { A paradigm of teaching knowledge is constructed, discovered, and transformed } \\
\text { by students. }\end{array}$ \\
\hline $\begin{array}{l}\text { Smith, B.L. \& } \\
\text { MacGregor (1992). }\end{array}$ & $\begin{array}{l}\text { An umbrella term for a variety of educational approaches involving joint } \\
\text { intellectual effort by students, or students and teachers together for understanding, } \\
\text { solutions, or meanings, or creating a product. }\end{array}$ \\
\hline
\end{tabular}

The second step was to review the studies done in Colombia about the implementation of CL (the population, study dates, education sector, aims and findings).

\section{What is the evidence of implementing $C L$ and the outcomes in studies done in Colombia?}

As it was previously mentioned, the studies chosen address aspects of CL implementation in educational settings. Therefore, there are evidences that show the implementation of this approach in different contexts and with different levels of education in Colombia. There are also evidences that this approach has been implemented with young learners, teenagers, young adults, 
and adults. In those contexts, CL was an excellent approach to develop cognitive, social and interpersonal skills.

Collaborative learning was applied in virtual classes, as it was shown in the previous section. The approach was reported to be successful as it enhanced students' performance. In addition, researchers mentioned that CL improves the students' intellectual level. Vygotsky (1978) states that students are able to perform at a higher intellectual level when working in collaborative situations as opposed to when working individually. Studies demonstrate that CL contributes positively in terms of knowledge and experiences to facilitate a better learning process. It was mentioned that CL improves problem-solving strategies because students are faced with new situations in which they must find a solution; they have to confront different situations and interpretations; and finally, they have to use their imaginations and creativity to solve a problem (Brown, 2008).

\section{What are the communicative skills taught through CL?}

According to the research found and analyzed, the skills that were improved through CL were mainly writing and reading; although there were some research studies based on integrated skills.

In one of the studies, it was found that CL improved writing skills. A group of students were asked to create a piece of writing and it was observed that students got easily involved discussing and agreeing about a topic in an imaginative and creative way. Dyson (2000) states that students are able to get immersed in a task and writing is then seen as a social dialogue as well as a peer collaboration task in the classroom. According to these findings, collaborative writing was associated with a social environment that engaged and encouraged students to link 
class activities with real life. In this study, students demonstrated an improvement in their writing skills process and achieved the final purpose of creating a good piece of writing with the appropriate structure and usage of language.

In the same way, studies demonstrated that CL improves reading and speaking skills. They were asked to solve a reading task in a collaborative way. Students felt more aware and selfconfident when asking questions of their partners. This way, they shared learning strategies that were implemented by the rest of members of the group. One of the most relevant findings in this study was that students got rid of fears as anxiety about the mistakes they made.

They felt confident asking their classmates about their doubts. At the end, a meaningful improvement in these specific communicative skills was noticed.

\section{What are the advantages of implementing this approach?}

According to the studies found in Colombia, CL promotes students' critical thinking, social and cognitive skills and self-confidence. One of the most relevant and interesting findings was that it promotes active exchange of ideas among students while promoting critical thinking; thus, increasing the interest and motivation of the group. According to Johnson and Johnson (1986), there is convincing evidence that collaborative teams achieve higher levels of thought and retain information longer than students who work quietly as individuals. Students have the opportunity to take part in a discussion, express ideas, be responsible for their learning and become critical thinkers (Totten, Sills, Digby, \& Russ, 1991).

CL is more effective than traditional methods because it enhances student satisfaction with the learning and classroom experience. It is also an effective approach in virtual courses because it reduces the frustration one may experience of working in isolation. Students feel more 
convinced doing a task when they know they can count on their classmates. Research projects

have shown that when implementing CL in virtual settings, excellent results were obtained.

Students accomplished the specific task though collaboration and group work. 


\section{Chapter 5: Conclusions and Pedagogical Implications}

\subsection{Significance of the results}

Due to the changes in education and the necessity to create more active methodologies for teaching English as a foreign language in Colombia, it has been necessary that teachers know about different student-centered methodologies, their implications and their teaching principles. The collaborative learning approach can help teachers address new challenges because society is constantly changing just as education is as well. Students have other necessities, interests and ways of learning; therefore, it is important that teachers change their traditional methodologies and start using different methods, to accomplish more active classes.

This paper has compiled different studies related to the implementation of CL; some of the articles retrieved in this study have provided insights regarding new ideas for further research on CL.

This literature review is a contribution for teachers since it includes studies done at all levels of education and shows the benefits of implementing this approach. It also provides teachers with a complete list of articles for further study, based on the teachers' interests. One of the most significant results here is that most of the studies on CL can be implemented in different educational levels with different population (children, teenagers, adults) in classroom courses and even in virtual courses. Studies demonstrated that CL is an effective way to promote successful learning and active learning processes.

\subsection{Limitations of the present study}

The present paper intended to include a number of studies about the implementation of CL in Colombia, as well as the implications of this implementation and its results. One of the 
limitations of the present study was that some articles were found on the online database at some universities in Bogota and sometimes the platforms did not work properly; therefore, it was difficult to download the articles.

There was a great variety of information about CL; but only a small amount of studies done in the EFL classroom was actually published in academic journals. Finally, some of the studies did not include complete information about findings or the research approach.

\subsection{Further research}

It is remarkable that a large body of research studies on CL was found not only in Colombia but in many other countries around the word; for instance, China, the UK and the USA. There is a large corpus of studies that was not included in the analysis but could be equally valuable for further research:

1. Studies related with the implementation of CL but in other subjects such science or chemistry.

2. Studies based on Cooperative Learning but not CL.

3. Studies based on Collaborative Networked Learning (CNL) and Computer-supported collaborative learning (CSCL)

It would be interesting to carry out a research about the implementation of Collaborative Networked Learning (CNL) and Computer-supported collaborative learning (CSCL) because these are the most recent versions of CL. Studying the relationship between CL and the use of new technologies in the field of language teaching in Colombia is needed because nowadays the number of virtual classes for undergraduate program, Master's programs and 
even $\mathrm{PhD}$ programs has increased. Thus, it will expand our knowledge of how to successfully implement CL in these contexts along with the resultant impact on students' performance.

It is important to mention that the main goal of this thesis is a systematic literature review. It is an important route to compile the existing knowledge, know the findings of research studies done in different context and settings in order to design new projects in areas that were not included in this thesis.

\subsection{Conclusion}

Although collaborative learning is not a current recent approach, it has been implemented during the last decades with successful results, considering the studies found and reviewed. Recent research demonstrates the benefits of the implementation of this approach; since it does not only improve cognitive skills but also social and interpersonal skills. One of the remarkable advantages of this approach is that learners have the opportunity to interact with other members of their class and carry out their tasks in a collaborative way while enhancing their relationships. It is well known that nowadays, children, teenagers and adults need to improve their social skills.

Teaching values in an educational context is relevant, but according to ones' own experience and hearing other's experience. It is sometimes a neglected activity. During my experience as a teacher, I noticed sometimes teachers focus more on developing cognitive skills on our students because we think if they demonstrate good results in local or international tests, we qualify as good teachers. Sometimes, institutions give more importance to improving cognitive skills to show good results about their educative process, in order to be competitive. 
But what about teaching values or social skills? It is something to reflect upon: how much time we devote to enhance values or social abilities on our students.

This systematic review points out that implementing CL indeed, helps students improve their social skills as they interact with peers by being respectful, tolerant and give a sense of a worth for others' opinions, ideas and contributions.

Due to the fact that social problems have increased today, it is important that educational institutions implement strategies, not only focused on teaching new knowledge and contents, but also strategies that promote social skills development. Social skills are the connection among people. Without them, social problems persist. Help from schools is needed (Johnson \& Johnson, 1998).

Teaching social skills is important not only to promote a good teaching environment in the class; but it is also necessary to prepare students for all aspects of life such as respect for diversity, acceptance of what is fair or unfair, showing concern for the common good by helping others.

It was also noticed that sometimes teachers' misconceptions, and lack of training, is a factor that makes the implementation of successful collaborative learning and teaching of social skills difficult within the classroom (Johnson and Holubec, 1998). Teachers sometimes believe that the implementation of CL refers to the fact students work in a group together to solve a problem or develop a final product; but they do not usually know the pedagogical and methodological implications of this approach.

According to the results of the systematic review, CL helps students to improve their academic achievement, social attitudes and behavior. Students are able to work together as a team, help each other and learn something of value from the collaborative activity. Therefore, it 
has a positive social influence in their lives since humans must continually interact with others in real situations to solve problems or get achievements as members of a community.

On the other hand, CL has also been a successful strategy to be implemented in virtual classes. Nowadays, technology has had great advances and online classes have increased. Internet in the present time is a worthy tool that allows communication among students and facilitates the work in long-distances groups. Research studies have demonstrated that CL can have an impact on students' development since it facilitates cognitive processes. That way, students feel part of a group in spite of the distance; and they have the opportunity to give and receive contributions from the group. This is reflected on the finals goals students achieve.

Finally, it is important that teachers get involved with CL as a way to possibly change misconceptions and get familiar with teaching by using CL and the positive aspects that this approach and other group approaches might have in order to facilitate students' learning processes. Teachers can implement more dynamic strategies in their classes, considering students' needs and interests instead of being the traditionalist teacher, avoiding interaction and just transmitting mere knowledge. 


\section{References}

Baines, E., Blatchford, P., \& Kutnick, P. (2003). Changes in grouping practices over primary and secondary school. International Journal of Educational Research, 39, 9e34

Baumann, J. F., Seifert-Kessell, N., \& Jones, L. A. (1992). Effect of think-aloud instruction on elementary students' comprehension monitoring abilities. Journal of Reading Behavior, 24(2), 143-172.

Baumeister, R. F., \& Leary, M. R. (1997). Writing narrative literature reviews. Review of General Psychology, 3, 311-320

Baumeister, R. F. (2013). Writing a literature review. In M. J. Prinstein \& M. D. Patterson (Eds.). The portable mentor: Expert guide to a successful career in psychology (pp. 119132; 2nd ed.). New York: Springer Science+ Business

Boote, D. N., \& Beile, P. (2005). Scholars Before Researchers: On the Centrality of the Dissertation Literature Review in Research Preparation. Educational Researcher, 34(6), 3-15. doi:10.3102/0013189x034006003

Bryman, A. \& Bell, E. (2007) "Business Research Methods”, 2nd edition. Oxford University Press.

Bruner, J. (1985). Vygotsky: An historical and conceptual perspective. Culture, communication, and cognition: Vygotskian perspectives, 21-34. London: Cambridge University Press.

Brown, J. S., \& Adler, R. P. (2008, January/February). Minds on fire: Open education, the long tail, and learning 2.0. EDUCAUSE, 17-

32. http://www.educause.edu/ir/library/pdf/ERM0811.pdf

Benson Phil \&Voller Peter. 1997. Autonomy and Independence in language learning. New York: Addison Wesley Longman.

Caicedo, P. (2016). Using Cooperative Learning to Foster the Development of Adolescents' English Writing Skills. Profile 18 (1), 21-38

Candy. 1991. Self-direction for lifelong learning. California: Jossey-Bass.

Carrell, P. (1998). Can reading strategies be successfully taught. Retrieved, June, 26, 2017, from http://www.jalt-publications.org/ttt/files/98/mar/carrell.html 
Cohen, E. (1994). Restructuring the classroom: conditions for productive small groups. Review of Educational Research, 64, 1e35

Cole, Karen Sanderson. (2012). Promoting Cooperative Learning in an expository writing course. Journal of International Education Research - Second Quarter, Volume 8, Number 2, pp.113-124

Centeno Moncada, E., Montenegro, G. M., Montes, S. M., Cristina, R., \& Acero, C. L. (2013). Collaborative learning teams: a strategy to foster self-directed language learning in al Colombian students (Doctoral dissertation).

Contreras Gutiérrez, K., \&Corzo, C. (2014). Enhancing fluency in speaking through the use of collaborative and self-directed speaking tasks (Doctoral dissertation).

Curtis, D. \& Lawson, M. (1999). Collaborative Online Learning: an exploratory case study. Retrieved from: https://www.researchgate.net/publication/241018374_Collaborative online learning an exploratory case study

Dickinson, L. 1987. Self-instruction in language learning. Cambridge: Cambridge University Press.

Cooper, H. M., Hedges, L. V., \& Valentine, J. C. (2008). The handbook of research synthesis and metanalysis (2nd ed.). New York: Russell Sage Foundation.

Denzin. N.K \& Lincoln. Y. ( 2003). The landscape of Qualitative Research. Theories and Issues. Second Edition. London: Sage.

Dillenbourgh, P., Baker, M., Blaye, A. \& O’Malley, C. (1995). The evolution of research on Collaborative Learning., Retrieved February 19, 2017, from CSCL-A brief overview.

Dyson, A. (2001). Dilemas, contradicciones y variedades de la inclusión. En M. Verdugo Y F. Jordan de Urríres (Eds.), Apoyos, autodeterminación y calidad de vida.

Espitia Peláez, J. D. (2014). Developing reading skills in a collaborative learning environment.

Ede, L., \& Lunsford, A. A. (2001). Collaboration and concepts of authorship. Publications of the Modern Language Association of America, 354-369.

Elola, I., and Oskoz, A. (2010). Collaborative Writing: fostering foreign language and writing Conventions Development. Language Learning \& Technology. Retrieved from http://lit.msu.edu/vol14num3/ elolaoskoz.pdf October 2010, Vol 14, (3), pp. 51-71

Espitia Pelaez, J. D. (2014). Developing reading skills in a collaborative learning environment.

Family Health International (2005). Qualitative Research Methods: a data collector's field guide. 2011. North Carolina 27709 USA. 
Forsyth, D. R. (2006). Conflict. In D. R. Forsyth (Ed.), Group Dynamics (5th ed., pp. 388-389). Wadsworth: Cengage Learning Belmont.

Galton, M., Hargreves, L., Comber, C., Wall, D., \& Pell, T. (1999). Changes in patterns of teacher interaction in primary classrooms: 1976e1996. British Educational Research Journal, 25, $23 \mathrm{e} 37$.

Gardner, R. C. (2001). Integrating motivation and second language acquisition. Canadian Association of Applied Linguistics Joint Plenary talk. May 30, 2005, London, Canada

Gillies, R. (2006). Teachers' and students' verbal behaviors during cooperative and small-group learning. British Journal of Educational Psychology, 76, 271-287.

Gillies, R. (2007). Cooperative learning: integrating theory and practice. U.S.A: Sage publications, Inc. Thousand Oaks, CA

Golub, J. (Ed). Focus on Collaborative Learning. Urbana, IL: National Council of Teachers of English, 1988.

Gokhale, A (1995) Journal of technology education. Volume 7, Number 1. Fall 1995

González, Y., Yinneth, Y., Saenz, L. F., Bermeo, J. A., \& Castañeda Chaves, A. F. (2013). The Role of Collaborative work in the development of elementary students' writing skills. Profile Issues in Teachers Professional Development,15(1), 11-25.

Hurd, S. (2005). Autonomy and the language learning learner. En: Holmberg, B.; y otros editores. Distance education and languages: Evolution and change. Londres: Multilingual Matters Limited

Johnson, D., \& Johnson, F. (2003). Joining together: Group theory and group skills (8th ed.). Boston: Allyn and Bacon.

Johnson, D.W., Johnson, R.T. \& Smith, K.A. (1991). Active Learning: Cooperation in the college classroom (p. 1-6). Edina, Minnesota; USA

Johnson, D. W; R. Johnson y E. Holubec (1993). Cooperation in the Classroom, 6 a ed., Edina, Minnesota, Interaction Book Company.

Lopera, E.F. (2013). Enhancing speaking skills through collaborative learning strategies. Universidad de La Sabana, Santa Fé de Bogota, Colombia. Retrieved from http://intellectum.unisabana.edu.co:8080/jspui/bitstream/10818/9274/1/Edwin\%20Fernne y\%20Lopera\%20Piedrahita\%20\%28TESIS\%29.pdf

Marshall, C., \& Rossman, G. (1999). Designing qualitative research (3rd ed.). Thousand Oaks, CA: Sage

MacGregor, J. "Collaborative Learning: Shared inquiry as a process of reform." In M. Svinicki, (Ed.) The changing face of college teaching. New Directions for Teaching and Learning, no. 42, San Francisco: Jossey-Bass, 1990 
Molina Farfán, Z. C., \& Mora Vélez, R. A. (2013). Collaborative learning and autonomy in EFL University Students.

Pemberton, H, D., et al. 1996. Taking control: Autonomy in language learning. Hong Kong: Hong Kong Press.

Quinn, P (2006). Cooperative learning and student motivation. Education and human development master's theses. 85http://digitalcommons.brockport.edu/ehd_theses/285

Rau, W. \&Heyl, B. S. (1990). Humanizing the college classroom: Collaborative learning and social organization among students. Teaching Sociology, 18, 141-155.

Slavin , R. E. (1989). Research on cooperative learning: An international perspective. Scandinavian Journal of Educational Research, 33(4), 231-243.

Slavin, R. E. (1997). Research on cooperative learning and achievement: A quarter century of research. Paper presented at the Annual Meeting of Pedagogical Psychology, Frankfurt, September.

Smith, B. L., \& Macgregor, J. T. (1992). What is collaborative learning? Collaborative Learning: A sourcebookfor higher education. Anti essays. Retrieved March 7, 2017 from http://www.antiessays.com/free-essays/81887.html

Stacey, E. (1999). Collaborative learning in an online environment. The Journal of Distance Education / Revue de l'Éducation à Distance, [Online] 14(2). Retrieved from http://www.jofde.ca/index.php/jde/article/viewArticle/154/379.

Sternberg, R. J. (1991). Editorial. Psychological Bulletin, 109, 3-4

Baumeister, R. F., \& Leary, M. R. (1997). Writing narrative literature reviews. Review of General Psychology, 3, 311-320.

Schug, M.C. Tarver, S., and Western, R.D. (2001). Direct instruction and the teaching of early reading: Wisconsin's teacher led insurgency. Mequon, WI: Wisconsin Policy Research Institute.

Totten, S., Sills, T., Digby, A., \& Russ, P. (1991). Cooperative learning: A guide to research. New York: Garland.

Thomson, C. K.. 1996. Self-assessment in self-directed learning: Issues of learner diversity. In: Pemberton, et al. (Eds.). Taking control: Autonomy in language learning. Hong Kong: Hong Kong University Press.

Vygotsky, L.S. (1962). Thought and Language. Cambridge, MA: MIT Press. (Original work published in 1934). 
Vygotsky, L. (1978). Mind in society: The development of higher psychological processes. Cambridge, MA: Harvard University Press.

Wenden, A. 1998. Learner strategies for learner autonomy. Hemel Hempstead: Prentice Hall. ZHANG Tian-xia. 2009. An empirical study on autonomy learning ability based on a new teaching Mode. Journal of Tianjin Foreign Languages Institute, 4, 75-80. (in Chinese)

Weber, R. P. (1990). Basic Content Analysis, 2nd ed. Newbury Park, CA.

Wong, L.-H., Chin, C.-K., Chen, W. \& Gao, P. (2009). An Innovative collaborative writing approach to improve chinese as L2 pupils" linguistic skills. Proceedings of international conference on computer-supported Collaborative Learning (pp.651-661), Rhodes Island, Greece. (Retrieved 15th May 2017) http://lhwong.home.nie.edu.sg/CSCL09wiki_writing.pdf

Worde, R. (2003). Students' perspectives on foreign language anxiety. Retrieved March 4, 2017, from http://www.vccaedu.org/inquiry/inquiry-spring2003/ i-81-worde.html 


\section{Appendix}

Appendix 1: Questionnaire for teachers

\section{QUESTIONNAIRE}

Objective:

This questionnaire aims to know the application of strategies related with Collaborative Learning or other grouping strategies and methods in the FL classroom.

Instructions:

Read the following questions and answer them according to your own experience.

1. Do you implement grouping strategies in the FL class? YES

NO

Why?

2. Which of the following approaches do you implement and why?

- Peer to peer learning

- Collaborative Learning

- Cooperative Learning

Explain reasons:

3. Could you mention some advantages or disadvantages of grouping strategies? 
Appendix 2: List of Articles included on the preliminary stage.

\begin{tabular}{|c|c|c|c|c|}
\hline & TITLE & AUTHOR & YEAR & POPULATION \\
\hline 1 & $\begin{array}{l}\text { The Role of Collaborative Work } \\
\text { in the Development of } \\
\text { Elementary Students' Writing } \\
\text { Skills }\end{array}$ & $\begin{array}{l}\text { Yuly Yinneth Yate } \\
\text { González, Luis Fernando } \\
\text { Saenz, Johanna Alejandra } \\
\text { Bermeo, Andrés Fernando } \\
\text { Castañeda Chaves }\end{array}$ & 2014 & $\begin{array}{l}\text { Elementary students from } \\
\text { Corporación Colegio San } \\
\text { Bonifacio de las Lanzas, a } \\
\text { private bilingual school in } \\
\text { lbague Colombia }\end{array}$ \\
\hline 2 & $\begin{array}{l}\text { Collaborative Project Work } \\
\text { Development in a Virtual } \\
\text { Environment with Low- } \\
\text { Intermediate Undergraduate } \\
\text { Colombian Students }\end{array}$ & Yakelin Salinas Vacca & 2012 & $\begin{array}{l}\text { A virtual English language } \\
\text { learning program at a public } \\
\text { university in Bogotá } \\
\text { (Colombia). }\end{array}$ \\
\hline 3 & $\begin{array}{l}\text { Collaborative Work as an } \\
\text { Alternative for Writing Research } \\
\text { Article }\end{array}$ & $\begin{array}{l}\text { Nancy Emilce Carvajal } \\
\text { Medina, Eliana Edith } \\
\text { Roberto Flórez }\end{array}$ & 2013 & $\begin{array}{l}\text { A group of nine students in } \\
\text { their tenth semester in the } \\
\text { Electronics Engineering } \\
\text { Faculty at Universidad Santo } \\
\text { Tomas. }\end{array}$ \\
\hline 4 & $\begin{array}{l}\text { Collaborative learning teams: a } \\
\text { strategy to foster self-directed } \\
\text { language learning in Colombian } \\
\text { students }\end{array}$ & $\begin{array}{l}\text { Centeno Moncada, } \\
\text { Esmith; Montenegro, } \\
\text { Geimy Marcela; Montes, } \\
\text { Sixta María; Cristina, } \\
\text { Rodríguez; Acero, Claudia } \\
\text { Lucia }\end{array}$ & 2013 & $\begin{array}{l}\text { Four state schools in } \\
\text { Colombia } \\
35 \text { participants } 11-19 \text { years } \\
\text { old. }\end{array}$ \\
\hline 5 & $\begin{array}{l}\text { Collaborative work with wikis in } \\
\text { the setting and monitoring } \\
\text { language learning objectives }\end{array}$ & $\begin{array}{l}\text { Santana Prieto, Boris } \\
\text { Ernesto; Acero Ríos, } \\
\text { Claudia Lucía, }\end{array}$ & 2013 & $\begin{array}{l}15 \text { adult learners at } \\
\text { intermediate level B1 } \\
\text { according to the Common } \\
\text { European Framework of } \\
\text { Reference (CEFR) at a } \\
\text { language institute }\end{array}$ \\
\hline 6 & $\begin{array}{l}\text { Enhancing Fluency in Speaking } \\
\text { Through the Use of Collaborative } \\
\text { and Self- Directed Speaking } \\
\text { Tasks. }\end{array}$ & $\begin{array}{l}\text { Barragán Torres, Carlos } \\
\text { Antonio }\end{array}$ & 2013 & $\begin{array}{l}\text { Five public schools and a } \\
\text { private university in which } \\
\text { students have an average of } \\
\text { four hours of English } \\
\text { instruction per week }\end{array}$ \\
\hline 7 & $\begin{array}{l}\text { Enhancing speaking skills } \\
\text { through the application of } \\
\text { collaborative learning strategies } \\
\text { in a Colombian public school. }\end{array}$ & $\begin{array}{l}\text { Lopera Piedrahita, Edwin } \\
\text { Ferney; }\end{array}$ & 2014 & $\begin{array}{l}\text { Students from a primary } \\
\text { school. }\end{array}$ \\
\hline 8 & $\begin{array}{l}\text { Collaborative Learning and } \\
\text { Autonomy in EFL University } \\
\text { Students }\end{array}$ & $\begin{array}{l}\text { Molina Farfán, Zaida } \\
\text { Carolina; Mora Vélez, Raúl } \\
\text { Alberto }\end{array}$ & 2013 & $\begin{array}{l}\text { Students of fourth semester of } \\
\text { Veterinary Medicine at a local } \\
\text { institution in Tunja }\end{array}$ \\
\hline 9 & $\begin{array}{l}\text { Developing reading skills in a } \\
\text { collaborative learning } \\
\text { environment }\end{array}$ & $\begin{array}{l}\text { Espitia Pelaez, Juan } \\
\text { Darwin; Cuesta Medina }\end{array}$ & 2014 & $\begin{array}{l}\text { Students from eleventh grade } \\
\text { from a private school. }\end{array}$ \\
\hline
\end{tabular}


Appendix 3: Articles related to collaborative learning and autonomy

\begin{tabular}{|c|c|c|c|c|}
\hline & TITLE & AUTHOR & YEAR & POPULATION \\
\hline 1 & $\begin{array}{l}\text { Approaching autonomous } \\
\text { learning through the } \\
\text { instruction of language } \\
\text { learning strategies focused on } \\
\text { the reading and writing skills in } \\
\text { an EFL setting in a public } \\
\text { school from Pereira. }\end{array}$ & $\begin{array}{l}\text { Katherine Liceth } \\
\text { Castaño Loaiza } \\
\text { Jennyfer Londoño } \\
\text { Suárez }\end{array}$ & 2012 & $\begin{array}{l}\text { A group of Eighth } \\
\text { graders in a school in } \\
\text { Pereira Colombia }\end{array}$ \\
\hline 2 & $\begin{array}{l}\text { Building up Autonomy Through } \\
\text { Reading Strategies }\end{array}$ & $\begin{array}{l}\text { Alexander Izquierdo } \\
\text { Castillo } \\
\text { Sonia Jiménez Bonilla }\end{array}$ & 2013 & $\begin{array}{l}\text { Six ninth grade students in a } \\
\text { rural public school in } \\
\text { Gachetá, Cundinamarca, } \\
\text { Colombia }\end{array}$ \\
\hline 3 & $\begin{array}{l}\text { Profiles of Autonomy in the } \\
\text { Field of Foreign Language }\end{array}$ & $\begin{array}{l}\text { Myriam Luna Cortés, } \\
\text { Diana K. Sánchez } \\
\text { Lujan }\end{array}$ & 2014 & $\begin{array}{l}\text { A group of four students, } \\
\text { they were in fifth semester } \\
\text { students in the } \\
\text { undergraduate program in } \\
\text { foreign languages at the } \\
\text { University of Pamplona }\end{array}$ \\
\hline 4 & $\begin{array}{l}\text { Guidance in Reading } \\
\text { Strategies: A First Step } \\
\text { Towards Autonomous } \\
\text { Learning in a Semi-Distance } \\
\text { Education Program }\end{array}$ & $\begin{array}{l}\text { Jahir Aguirre Morales, } \\
\text { Bertha Ramos } \\
\text { Holguín }\end{array}$ & 2014 & $\begin{array}{l}54 \text { students. The students } \\
\text { were attending English I } \\
\text { and II courses in the } \\
\text { Distance Business } \\
\text { Administration Program. }\end{array}$ \\
\hline 5 & $\begin{array}{l}\text { Promoting Learner Autonomy } \\
\text { Through Teacher-Student } \\
\text { Partnership Assessment in an } \\
\text { American High School: A } \\
\text { Cycle of Action Research }\end{array}$ & Edgar Picón Jácome & 2012 & Students from a high school \\
\hline 9 & $\begin{array}{l}\text { Building up Autonomy } \\
\text { Through Reading Strategies }\end{array}$ & $\begin{array}{l}\text { Alexander Izquierdo } \\
\text { Castillo, Sonia } \\
\text { Jiménez Bonilla }\end{array}$ & 2012 & $\begin{array}{l}\text { A group of six students in } \\
\text { ninth grade in a small rural } \\
\text { agricultural public school }\end{array}$ \\
\hline
\end{tabular}


Appendix 4: Articles found about Collaborative Learning

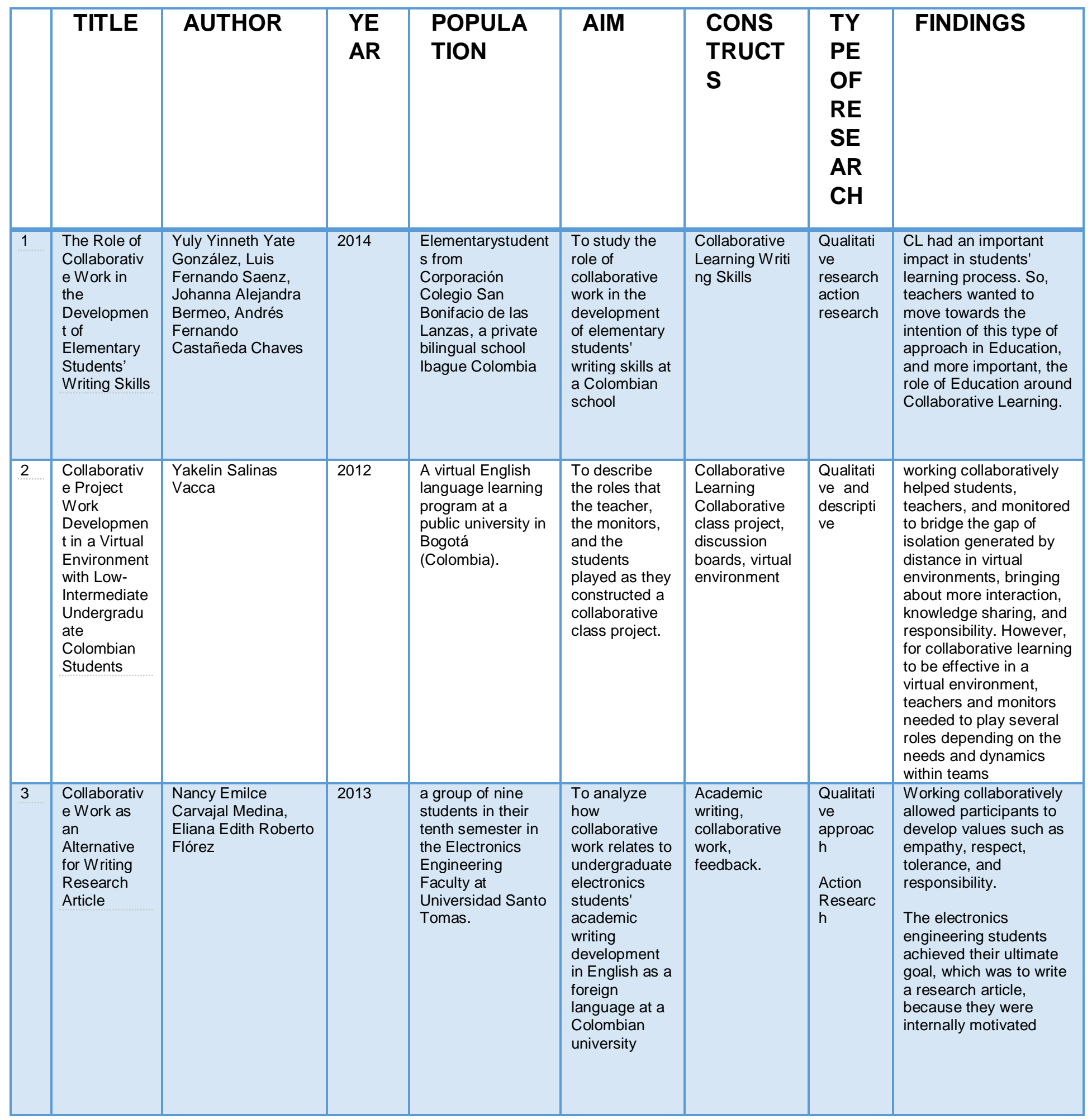


COLLABORATIVE LEARNING IN THE COLOMBIAN EDUCATIONAL SYSTEM 63

\begin{tabular}{|c|c|c|c|c|c|c|c|}
\hline 4 & $\begin{array}{l}\text { Collaborativ } \\
\text { e learning } \\
\text { teams: a } \\
\text { strategy to } \\
\text { foster self- } \\
\text { directed } \\
\text { language } \\
\text { learning in } \\
\text { Colombian } \\
\text { students }\end{array}$ & $\begin{array}{l}\text { Centeno Moncada, } \\
\text { Esmith; Montenegro, } \\
\text { Geimy } \\
\text { Marcela; Montes, } \\
\text { Sixta María; Cristina, } \\
\text { Rodríguez; Acero, } \\
\text { Claudia Lucia }\end{array}$ & 2013 & $\begin{array}{l}\text { four state schools } \\
\text { in Colombia } \\
35 \text { participants } 11 \text { - } \\
19 \text { years old. }\end{array}$ & $\begin{array}{l}\text { Collaborative } \\
\text { learning } \\
\text { Self-directed } \\
\text { language }\end{array}$ & $\begin{array}{l}\text { Action } \\
\text { research } \\
\text { Descripti } \\
\text { ve } \\
\text { method }\end{array}$ & $\begin{array}{l}\text { CL created a positive } \\
\text { learning environment } \\
\text { because it may have } \\
\text { decreased the effects of } \\
\text { the anxiety often } \\
\text { produced by complex } \\
\text { content, and abstract } \\
\text { concepts or ideas. } \\
\text { Students could express } \\
\text { their fears, ideas, } \\
\text { biases, or lack of } \\
\text { understanding }\end{array}$ \\
\hline 5 & $\begin{array}{l}\text { Collaborativ } \\
\text { e work with } \\
\text { wikis in the } \\
\text { setting and } \\
\text { monitoring } \\
\text { language } \\
\text { learning } \\
\text { objectives }\end{array}$ & $\begin{array}{l}\text { Santana Prieto, } \\
\text { Boris Ernesto; Acero } \\
\text { Ríos, Claudia Lucía, }\end{array}$ & 2013 & $\begin{array}{l}15 \text { adult learners } \\
\text { at intermediate } \\
\text { level B1 according } \\
\text { to the Common } \\
\text { European } \\
\text { Framework of } \\
\text { Reference (CEFR) } \\
\text { at a language } \\
\text { institute }\end{array}$ & & & $\begin{array}{l}\text { Students participated in } \\
\text { the wikis and helped to } \\
\text { others making } \\
\text { contributions. } \\
\text { Students could assess } \\
\text { the outcomes of their } \\
\text { language objectives and } \\
\text { they accomplished their } \\
\text { languages learning } \\
\text { process }\end{array}$ \\
\hline 6 & $\begin{array}{l}\text { Enhancing } \\
\text { Fluency in } \\
\text { Speaking } \\
\text { Through the } \\
\text { Use of } \\
\text { Collaborativ } \\
\text { e and Self- } \\
\text { Directed } \\
\text { Speaking } \\
\text { Tasks. }\end{array}$ & $\begin{array}{l}\text { Barragán Torres, } \\
\text { Carlos Antonio }\end{array}$ & 2013 & $\begin{array}{l}\text { Five public } \\
\text { schools and a } \\
\text { private university } \\
\text { in which students } \\
\text { have an average } \\
\text { of four hours of } \\
\text { English instruction } \\
\text { per week }\end{array}$ & & & $\begin{array}{l}\text { Students enjoyed } \\
\text { working collaboratively. } \\
\text { Students increased oral } \\
\text { interaction in the foreign } \\
\text { language and make } \\
\text { their learning process } \\
\text { meaningful. } \\
\text { Students gradually } \\
\text { began to diminish their } \\
\text { fear of talking and took } \\
\text { the risk of participating } \\
\text { and interacting in the } \\
\text { target language }\end{array}$ \\
\hline 7 & $\begin{array}{l}\text { Enhancing } \\
\text { speaking } \\
\text { skills } \\
\text { through the } \\
\text { application } \\
\text { of } \\
\text { collaborative } \\
\text { learning } \\
\text { strategies in } \\
\text { a Colombian } \\
\text { public } \\
\text { school. }\end{array}$ & $\begin{array}{l}\text { Lopera Piedrahita, } \\
\text { Edwin Ferney; }\end{array}$ & 2014 & $\begin{array}{l}\text { Students from } \\
\text { primary school. }\end{array}$ & & & \\
\hline 8 & $\begin{array}{l}\text { Collaborativ } \\
\text { e Learning } \\
\text { and } \\
\text { Autonomy in } \\
\text { EFL } \\
\text { University } \\
\text { Students }\end{array}$ & $\begin{array}{l}\text { Molina Farfán, Zaida } \\
\text { Carolina; Mora } \\
\text { Vélez, Raúl Alberto }\end{array}$ & 2013 & $\begin{array}{l}\text { Students of fourth } \\
\text { semester of } \\
\text { Veterinary } \\
\text { Medicine at a local } \\
\text { institution in Tunja }\end{array}$ & & & \\
\hline 9 & $\begin{array}{l}\text { Developing } \\
\text { reading } \\
\text { skills in a } \\
\text { collaborative } \\
\text { learning } \\
\text { environment }\end{array}$ & $\begin{array}{l}\text { Espitia Pelaez, Juan } \\
\text { Darwin; Cuesta } \\
\text { Medina }\end{array}$ & 2014 & $\begin{array}{l}\text { Students from } \\
\text { eleventh grade } \\
\text { from a private } \\
\text { school. }\end{array}$ & & & \\
\hline
\end{tabular}




\section{Appendix 5. Mind maps}

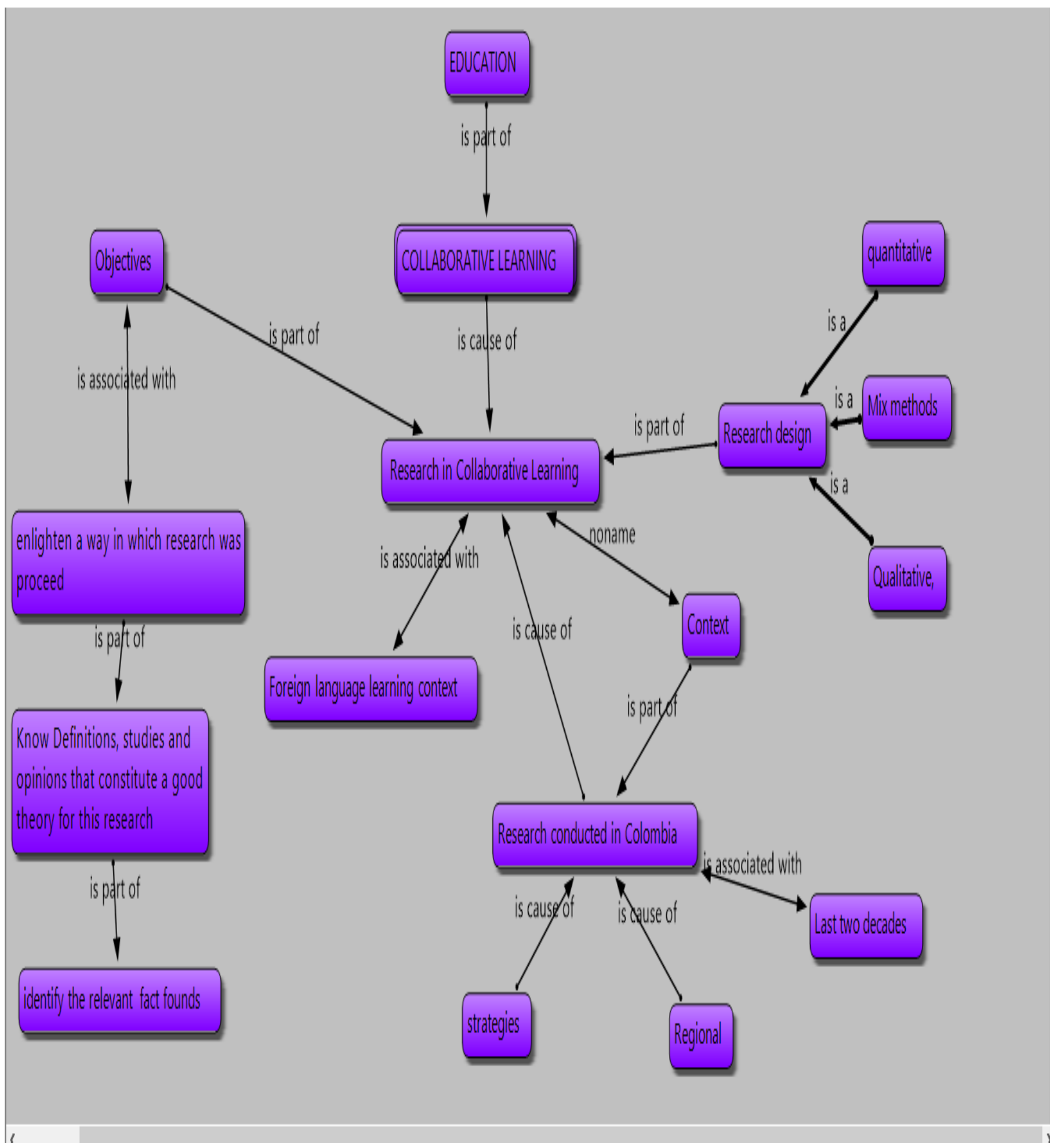




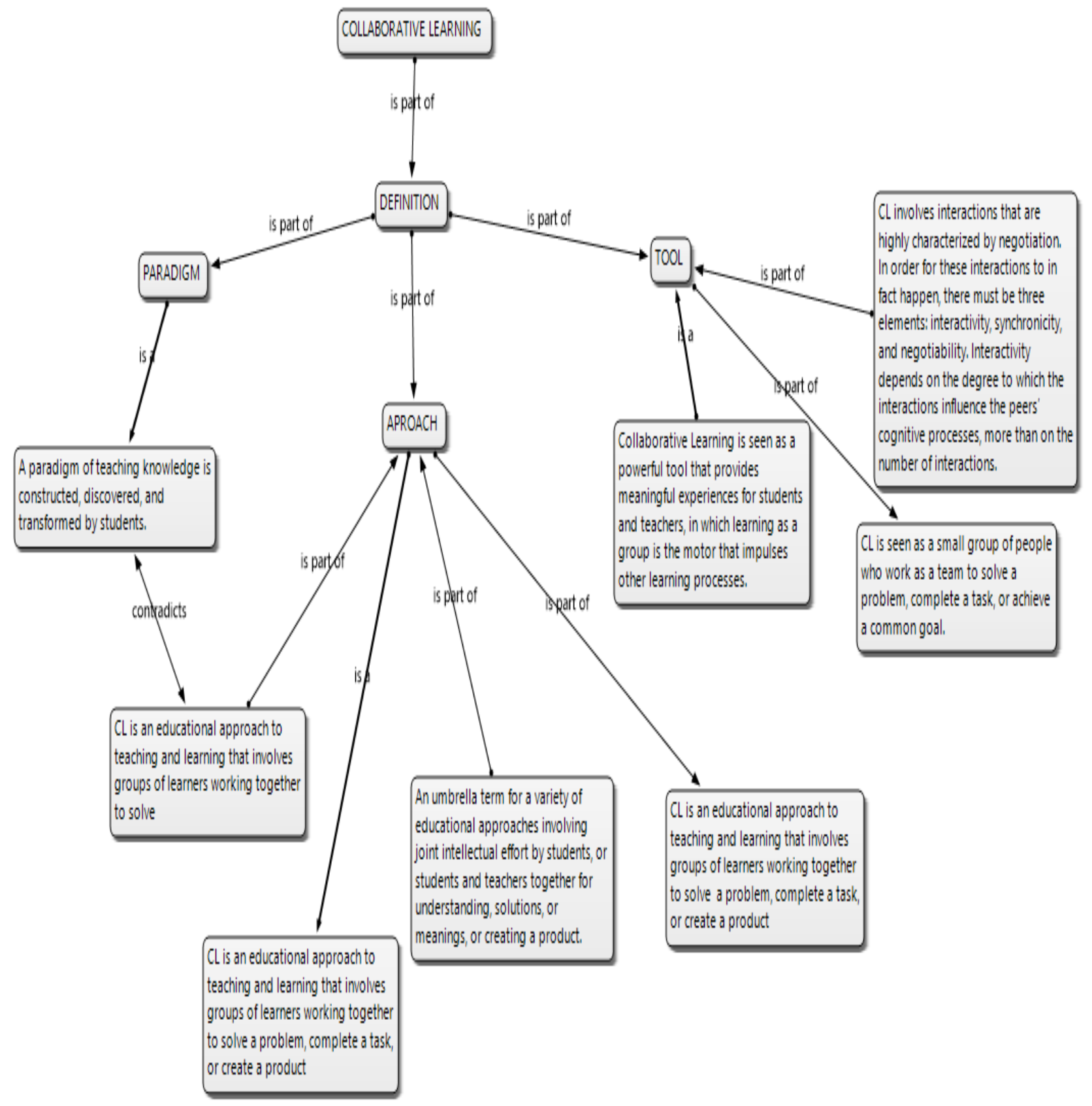

